\title{
Burial and Exhumation History of the Lujing Uranium Ore Field, Zhuguangshan Complex, South China: Evidence from Low-Temperature Thermochronology
}

\author{
Yue Sun ${ }^{1, *} \mathbb{C}$, Barry P. Kohn ${ }^{2} \mathbb{D}$, Samuel C. Boone ${ }^{2} \mathbb{D}$, Dongsheng Wang ${ }^{3}$ and Kaixing Wang ${ }^{1}$ \\ 1 State Key Laboratory of Nuclear Resources and Environment, School of Earth Sciences, East China University \\ of Technology, Nanchang 330013, China; xy2gmo02@ecut.edu.cn \\ 2 School of Earth Sciences, The University of Melbourne, Victoria 3010, Australia; \\ b.kohn@unimelb.edu.au (B.P.K.); samuel.boone@unimelb.edu.au (S.C.B.) \\ 3 Institute of Mineral Resources, Chinese Academy of Geological Sciences, Beijing 100081, China; \\ wangdongsheng@cags.ac.cn \\ * Correspondence: sunyue@ecut.edu.cn
}

check for

updates

Citation: Sun, Y.; Kohn, B.P.; Boone, S.C.; Wang, D.; Wang, K. Burial and Exhumation History of the Lujing Uranium Ore Field, Zhuguangshan Complex, South China: Evidence from Low-Temperature Thermochronology. Minerals 2021, 11, 116. https:// doi.org/10.3390/min11020116

Received: 17 September 2020

Accepted: 18 January 2021

Published: 24 January 2021

Publisher's Note: MDPI stays neutral with regard to jurisdictional claims in published maps and institutional affiliations.

Copyright: (c) 2021 by the authors. Licensee MDPI, Basel, Switzerland. This article is an open access article distributed under the terms and conditions of the Creative Commons Attribution (CC BY) license (https:// creativecommons.org/licenses/by/ $4.0 /)$.

\begin{abstract}
The Zhuguangshan complex hosts the main uranium production area in South China. We report (U-Th)/He and fission track thermochronological data from Triassic-Jurassic mineralized and non-mineralized granites and overlying Cambrian and Cretaceous sandstone units from the Lujing uranium ore field (LUOF) to constrain the upper crustal tectono-thermal evolution of the central Zhuguangshan complex. Two Cambrian sandstones yield reproducible zircon (U-Th)/He (ZHe) ages of 133-106 Ma and low effective uranium (eU) content (270-776 ppm). One Upper Cretaceous sandstone and seven Mesozoic granites are characterized by significant variability in ZHe ages (154-83 Ma and 167-36 Ma, respectively), which show a negative relationship with eU content (244-1098 ppm and 402-4615 ppm), suggesting that the observed age dispersion can be attributed to the effect of radiation damage accumulation on ${ }^{4} \mathrm{He}$ diffusion. Correspondence between $\mathrm{ZHe}$ ages from sandstones and granites indicates that surrounding sedimentary rocks and igneous intrusions supplied sediment to the Cretaceous-Paleogene Fengzhou Basin lying adjacent to the LUOF. The concordance of apatite fission track (AFT) central ages (61-54 Ma) and unimodal distributions of confined track lengths of five samples from different rock units suggest that both sandstone and granite samples experienced a similar cooling history throughout the entire apatite partial annealing zone $\left(\sim 110-60^{\circ} \mathrm{C}\right)$. Apatite (U-Th-Sm)/He (AHe) ages from six non-mineralized samples range from 67 to $19 \mathrm{Ma}$, with no apparent correlation to eU content (2-78 ppm). Thermal history modeling of data suggests that the LUOF experienced relatively rapid Early Cretaceous cooling. In most samples, this was followed by the latest Early Cretaceous-Late Cretaceous reheating and subsequent latest Late Cretaceous-Recent cooling to surface temperatures. This history is considered as a response to the transmission of far-field stresses, involving alternating periods of regional compression and extension, related to paleo-Pacific plate subduction and subsequent rollback followed by Late Paleogene-Recent India-Asia collision and associated uplift and eastward extrusion of the Tibetan Plateau. Thermal history models are consistent with the Fengzhou Basin having been significantly more extensive in the Late Cretaceous-Early Paleogene, covering much of the LUOF. Uranium ore bodies which may have formed prior to the Late Cretaceous may have been eroded by as much as $\sim 1.2$ to $4.8 \mathrm{~km}$ during the latest Late Cretaceous-Recent denudation.
\end{abstract}

Keywords: zircon and apatite (U-Th)/He; apatite fission track; Fengzhou Basin; Lujing uranium ore field; South China

\section{Introduction}

South China has experienced a long history of intra-plate tectonic deformation accompanied by multiple periods of granitic magmatism, resulting in a favorable ore mineralization environment [1,2]. Vein-type hydrothermal uranium deposits in South China 
(Figure 1) are hosted in granitic, volcanic, and carbonaceous-siliceous pelitic sedimentary rocks, which formed mainly during Cretaceous-Tertiary post-orogenic extension [3,4]. The Lujing uranium ore field (LUOF), located in the central Zhuguangshan complex, is one of the main areas of granite-related endo- and exo-contact uranium deposits in South China. Uranium deposits were discovered in Lujing in the 1950s. After decades of subsequent mining and research, the isotope geochronology of host rocks and mineralization ages [5-8], features and genesis of the deposit [9-11], and ore-forming structures and fluids [12-14] of the LUOF are now well characterized. However, the post-mineralization exhumation history, crucial for assessing modern ore preservation, remains poorly understood.

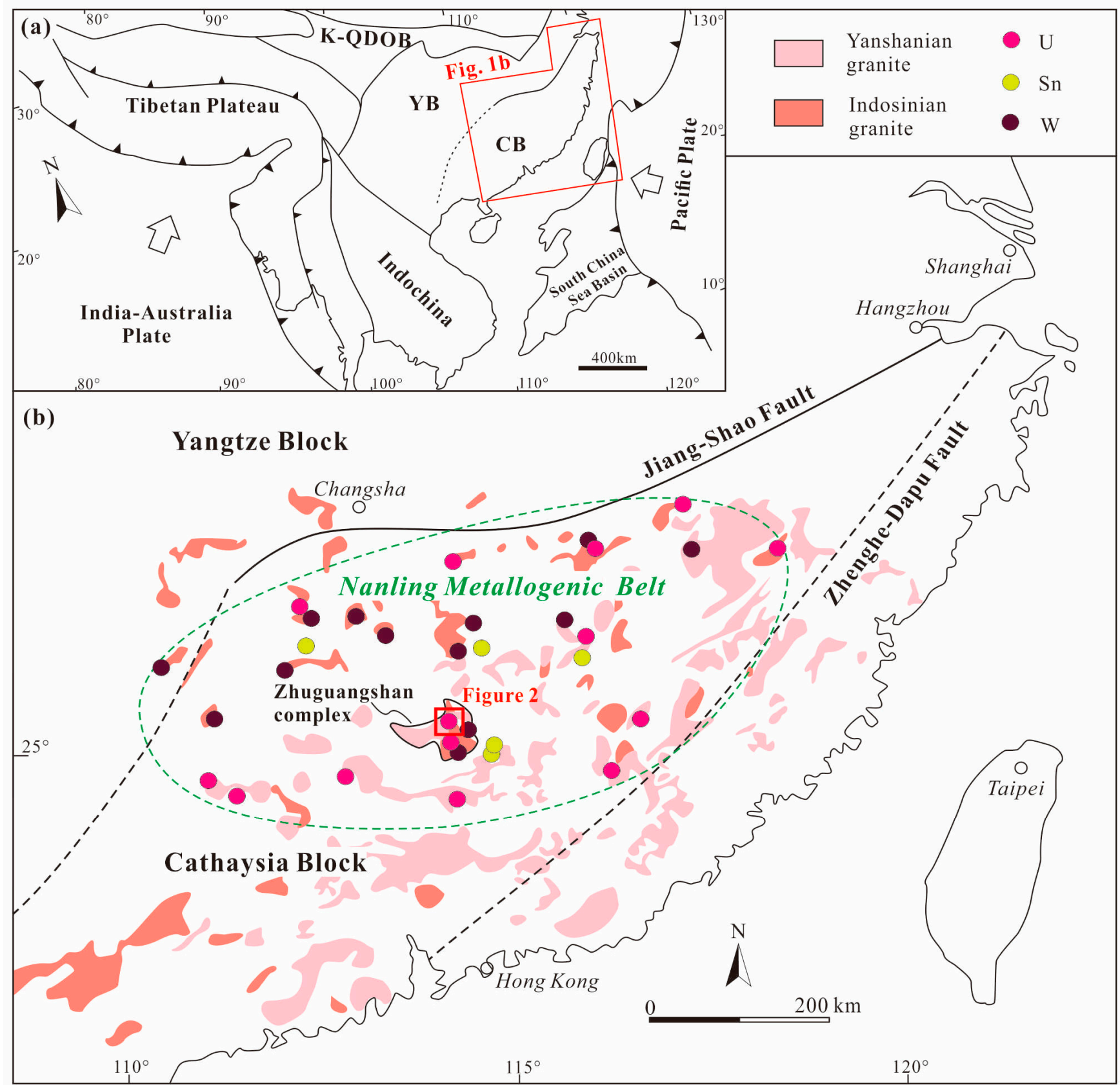

Figure 1. (a) Simplified geological map of South China showing the main tectonic units and (b) the location of $\mathrm{W}, \mathrm{Sn}$, and $\mathrm{U}$ deposits within the study region (modified after [42]). CB = Cathaysia Block, YB = Yangtze Block, $\mathrm{K}-\mathrm{QDOB}=$ Kunlun-Qingling-Dabie Orogen Belt. 
Constraining the low-temperature thermal history of an ore field is not only critical for understanding the role of exhumation in the temporal-spatial distribution of ore deposits, but it may also enable an assessment to be made regarding the preservation of ore bodies (e.g., [15-18]). Low-temperature thermochronometers, such as the zircon and apatite (U$\mathrm{Th}) / \mathrm{He}$ (ZHe, AHe) and apatite fission track (AFT) systems, allow for the upper-crustal cooling history of rocks between temperatures of $\sim 210$ and $30{ }^{\circ} \mathrm{C}$ to be reconstructed (e.g., [19-21]). These methods are therefore particularly useful for constraining the timing and magnitude of tectono-thermal processes operating from near-surface to a crustal depth of $~ 7-10 \mathrm{~km}$ (e.g., [22]), such as post-mineralization exhumation and erosion histories of ore deposits $[16,23]$ and, in some instances, the timing of metallogenesis of low-temperature hydrothermal deposits [15].

In this study, we present ZHe, AFT, and AHe data and thermal history models for mineralized and non-mineralized granitoid intrusions and overlying sandstones from the LUOF in order to: (i) reconstruct the Cretaceous-Recent time-temperature (t-T) history, and (ii) assess the state of preservation of the LUOF uranium ore bodies.

\section{Geological Setting}

The South China Block (SCB) is composed of two separate terranes, the Yangtze Block to the northwest and the Cathaysia Block to the southeast, which were amalgamated during the early Neoproterozoic (850-820 Ma) (Figure 1a) [24-26]. During the Mesozoic and Tertiary, the SCB experienced episodic intra-continental extension and magmatic activity caused by northwestward subduction of the paleo-Pacific plate [4,27], resulting in the development of NE-NNE trending normal faults and rift basins throughout the region. The present tectonic landscape of the SCB continues to be influenced by interactions with the surrounding India-Australia, Eurasian, and Pacific Plates (e.g., [28-30]). The E-W trending Nanling Metallogenic Belt, located within the central SCB (Figure 1b), contains abundant hydrothermal mineral deposits, including $\mathrm{U}, \mathrm{W}, \mathrm{Sn}, \mathrm{Mo}, \mathrm{Pb}$, and $\mathrm{Zn}$, which formed during major episodes of Mesozoic tectonic-magmatic activity [31-33]. Previously published zircon U-Pb, molybdenite Re-Os, and muscovite ${ }^{40} \mathrm{Ar} /{ }^{39} \mathrm{Ar}$ ages from the Nanling Metallogenic Belt indicate that the $\mathrm{Cu}-\mathrm{Mo}$ porphyry and their related hydrothermal $\mathrm{Pb}-\mathrm{Zn}-\mathrm{Ag}$ deposits were formed between 175 and $160 \mathrm{Ma}$, while W-Sn deposits formed between 160 and $150 \mathrm{Ma}$ [2,34-36]. Uranium deposits, hosted by Jurassic to Precambrian rocks, were formed during different mineralization episodes between 135 and $45 \mathrm{Ma}$, based on $\mathrm{U}-\mathrm{Pb}$ age determinations of primary pitchblende from different deposits in the Nanling Metallogenic Belt [3].

The Lujing uranium ore field (LUOF) is located within the central Zhuguangshan complex of the Nanling Metallogenic Belt (Figures $1 \mathrm{~b}$ and 2). The basement of the field comprises Precambrian and Cambrian epi-metamorphic sandstones originating from shallow marine clastic rocks, overlain by Ordovician argillite, silty slate, and carbonate rocks $[9,37]$. There are no published U-Pb zircon ages for these units. These are intruded by widespread Indosinian and Yanshanian intermediate to acid igneous rocks and minor Caledonian granites. In the study area, zircon U-Pb SHRIMP ages of $235 \pm 1 \mathrm{Ma}$ and $239 \pm 5 \mathrm{Ma}$ have been reported for the Indosinian intrusives [5,38]. Wu et al. [39] obtained Rb-Sr isotope data yielding a $155 \pm 5 \mathrm{Ma}$ age for a Yanshanian granite. Upper Cretaceous red-colored conglomerates and sandstones rest unconformably on the Cambrian successions. A series of Cretaceous-Paleogene mafic dikes crosscut the LUOF [40]. 

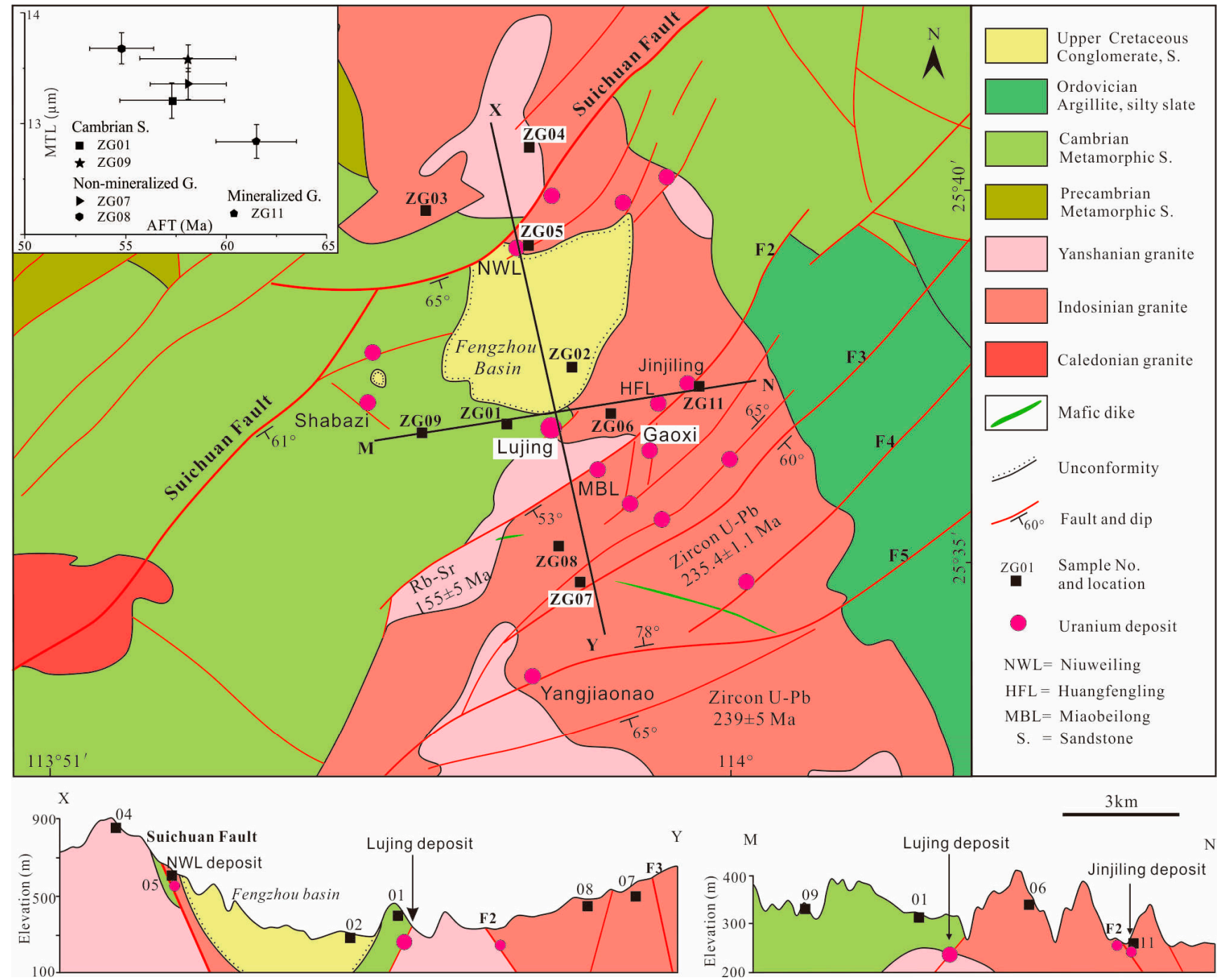

Figure 2. Geological map and cross-sections of the Lujing uranium ore field region showing sample locations, with distribution of uranium deposits and intrusive ages of the Indosinian and Yanshanian granites, for which the references cited do not provide exact sample locations (modified after [6]).

The region is dissected by a series of major NE-trending faults such as the Suichuan Fault, F2, F3, F4, and F5 (Figure 2). The Suichuan Fault developed as a thrust fault during a Late Jurassic-earliest Cretaceous compressive tectonic regime resulting from paleo-Pacific plate subduction beneath the Cathaysia Block [10,41,42]. During the Cretaceous and Paleogene, the tectonic setting generally switched from compression to extension due to rollback and eastward retreat of the subduction zone [3,30,42], giving rise to normal reactivation of the Suichuan Fault and the formation of other NE-trending normal faults in the region. This resulted in formation of the Late Cretaceous-Paleogene Fengzhou Basin within the extended Cathaysia Block (Figure 2), which covers an area of $\sim 16 \mathrm{~km}^{2}$ and hosts a sequence of coarse fluvio-lacustrine sandstones and conglomerates attaining present-day thicknesses of $>360 \mathrm{~m}$ [9]. No independent temperature constraints, such as organic matter maturity or fluid inclusion data, have been reported from the Fengzhou Basin. However, regional outliers of red detrital rocks located in peripheral areas [43], including a relatively extensive outcrop to the west of the Fengzhou Basin (see Figure 2), indicate that the basin may have once been significantly larger. 
Hydrothermal alteration and uranium mineralization in the LUOF mainly developed within or at the outer contact of the Indosinian-Yanshanian granite belt during several metallogenic pulses, based on U-Pb age determinations of pitchblende dated between 105 and $47 \mathrm{Ma}$ [11]. This range covers a slightly different time span than reported in an earlier study for the entire belt [3]. This period broadly corresponds to a period of Cretaceous-Tertiary crustal dilation and mafic dike intrusion that affected much of South China [3,44,45]. Oreforming conditions of uranium deposits in the LUOF region fall in between temperatures of $\sim 150$ and $270{ }^{\circ} \mathrm{C}$ [11], with pressures of 152-507 bars [10]. These approximately correspond to depths of 0.6 to $2.0 \mathrm{~km}$ under lithostatic conditions (assuming $250 \mathrm{bar} / \mathrm{km}$ ) or 1.5 to $5.0 \mathrm{~km}$ under hydrostatic conditions (assuming $100 \mathrm{bar} / \mathrm{km}$ ) [3]. However, mineralization conditions probably ranged somewhere between hydrostatic and lithostatic pressures because the ore bodies were formed mainly along the NE-trending faults [9,41].

\section{Sampling and Methodology}

Seven granites and three sandstones were collected from the LUOF along two principal transects (X-Y, M-N, Figure 2), with coordinates and lithologies listed in Table 1. Sample ZG04 was collected from a Yanshanian granite, while six samples ZG03, 05-08, and 11 were obtained from the same Indosinian granite. Mineralized samples ZG05 and 11 were collected from near the Niuweiling and Jinjiling uranium deposits, respectively. Sample ZG02 is from an Upper Cretaceous sandstone in the Fengzhou Basin, and samples ZG01 and 09 are from Cambrian sandstones located southwest of the basin (Figure 2). All samples, excluding mineralized samples ZG05 and 11, were collected from a distance of at least $50 \mathrm{~m}$ from the main faults.

Table 1. Sample locations and lithological information from the Lujing uranium ore field.

\begin{tabular}{|c|c|c|c|c|c|c|c|}
\hline Lithology-Age & Sample & Longitude ${ }^{\circ} \mathrm{E}$ & Latitude ${ }^{\circ} \mathbf{N}$ & Elevation (m) & $\mathrm{ZHe}$ & AFT & $\mathrm{AHe}$ \\
\hline Sandstone-Cambrian & ZG01 & $113^{\circ} 57^{\prime} 27.33^{\prime \prime}$ & $25^{\circ} 37^{\prime} 10.47^{\prime \prime}$ & 322 & $x$ & $x$ & $x$ \\
\hline Sandstone-Cambrian & ZG09 & $113^{\circ} 56^{\prime} 28.37^{\prime \prime}$ & $25^{\circ} 37^{\prime} 09.53^{\prime \prime}$ & 340 & $x$ & $x$ & $x$ \\
\hline Sandstone-Cretaceous & ZG02 & $113^{\circ} 58^{\prime} 24.51^{\prime \prime}$ & $25^{\circ} 37^{\prime} 33.61^{\prime \prime}$ & 281 & $x$ & - & $x$ \\
\hline Granite-Triassic & ZG03 & $113^{\circ} 56^{\prime} 32.81^{\prime \prime}$ & $25^{\circ} 39^{\prime} 43.41^{\prime \prime}$ & 530 & $x$ & - & $x$ \\
\hline Granite-Jurassic & ZG04 & $113^{\circ} 58^{\prime} 05.71^{\prime \prime}$ & $25^{\circ} 40^{\prime} 41.11^{\prime \prime}$ & 849 & $x$ & - & - \\
\hline Granite-Triassic & ZG06 & $113^{\circ} 58^{\prime} 43.43^{\prime \prime}$ & $25^{\circ} 37^{\prime} 10.94^{\prime \prime}$ & 332 & $x$ & - & - \\
\hline Granite-Triassic & ZG07 & $113^{\circ} 57^{\prime} 44.14^{\prime \prime}$ & $25^{\circ} 35^{\prime} 02.87^{\prime \prime}$ & 360 & $x$ & $x$ & $x$ \\
\hline Granite-Triassic & ZG08 & $113^{\circ} 57^{\prime} 35.57^{\prime \prime}$ & $25^{\circ} 35^{\prime} 36.64^{\prime \prime}$ & 312 & $x$ & $x$ & $x$ \\
\hline Mineralized granite-Triassic & ZG05 & $113^{\circ} 57^{\prime} 52.81^{\prime \prime}$ & $25^{\circ} 39^{\prime} 17.86^{\prime \prime}$ & 384 & $x$ & - & $x$ \\
\hline Mineralized granite-Triassic & ZG11 & $113^{\circ} 59^{\prime} 45.85^{\prime \prime}$ & $25^{\circ} 37^{\prime} 22.06^{\prime \prime}$ & 304 & $x$ & $x$ & $x$ \\
\hline
\end{tabular}

Note: $\mathrm{ZHe}=$ zircon $(\mathrm{U}-\mathrm{Th}) / \mathrm{He}, \mathrm{AFT}=$ apatite fission track, $\mathrm{AHe}=$ apatite $(\mathrm{U}-\mathrm{Th}) / \mathrm{He}$.

Zircon and apatite grains were separated by standard crushing and sieving techniques, followed by ultrasonic cleaning in distilled water, and then separated using magnetic and density liquid techniques. ZHe, AFT, and AHe analyses were carried out in the School of Earth Sciences, University of Melbourne. Grain geometry measurements for (U-Th)/He analyses were recorded for calculation of an $\alpha$-correction factor and most grains selected had widths $>70 \mu \mathrm{m}$ in order to maximize helium gas values and minimize the $\alpha$ ejection correction $\left(F_{T}\right)$ [46]. Reference materials dated as unknowns to assess the quality of apatite and zircon (U-Th)/He analyses were Durango [47] and Fish Canyon Tuff [48], respectively. All analytical procedures followed those described in Gleadow et al. [48], with the exception that ${ }^{233} \mathrm{U}$ and ${ }^{229} \mathrm{Th}$ spikes were applied for ZHe analyses. AFT analysis was performed using FastTracks on image sets captured using TrackWorks (Autoscan Systems Pty. Ltd., Melbourne, Victoria, Australia) after etching in $5 \mathrm{M} \mathrm{HNO}_{3}$ for $20 \mathrm{sec}$ at $20^{\circ} \mathrm{C}$. The uranium concentration of each grain was determined by LA-ICP-MS, using Durango apatite as a secondary reference material. 
Thermal history models of 10 samples were generated using QTQt (version 5.6.0) [49]. For AFT data, the annealing model of Ketcham et al. [50] and c-axis projected confined tracks were applied. Dpar measurements were used as the kinetic parameter for AFT annealing. The radiation damage He diffusion models of Gautheron et al. [51] and Guenthner et al. [52] were used for AHe and ZHe data, respectively. Only He grains with 1 and 2 terminations were modeled. The present-day surface temperature was set at $20 \pm 5{ }^{\circ} \mathrm{C}$. Additional time-temperature (t-T) constraints for Cambrian (509-497 Ma, $20 \pm 5{ }^{\circ} \mathrm{C}$ ) and Upper Cretaceous (101-66 Ma, $20 \pm 5{ }^{\circ} \mathrm{C}$ ) sandstones were also applied, corresponding to their depositional ages, and an assumed paleo-temperature similar to present-day surface conditions.

To test if the observed thermochronology data are consistent with the paleo-Fengzhou Basin having been larger than its modern-day extent, as suggested by the presence of residual red detritus from surrounding areas [43], thermal history models were also run with an additional Late Cretaceous t-T constraint, requiring samples to be relatively close to near-surface during basin formation. The applied temperature range for this additional constraint varied depending on the proximity of samples to the modern-day Fengzhou Basin, allowing for a modest thickness of basement to have been removed along with the periphery of the Fengzhou Basin during the Cenozoic. For the nearest samples (ZG01, $09,05,06$, and 11), a temperature range of $15-35^{\circ} \mathrm{C}$ was used; for distal samples ZG03, 04,07 , and 08 , a broader range of $20-60^{\circ} \mathrm{C}$ was applied. In all cases, the observed data are more consistent with samples having resided at near-surface temperatures in the Late Cretaceous, supporting the inference of a once more extensive Fengzhou Basin.

\section{Results}

\subsection{Zircon $(U-T h) / H e$ Data}

Thirty-eight single-grain ZHe ages, obtained from all samples listed in Table 1, are presented in Table 2. All grains selected for analysis under a binocular microscope possessed two crystal terminations (excluding one grain from sample ZG05; see Table 2) and were free of any discernible inclusions, cracks, or obvious metamict textures/colors. ZHe data are characterized by significant variability, with ages ranging from 167 to $36 \mathrm{Ma}$. They show a negative trend with respect to effective uranium concentration (eU; eU $=\mathrm{U}$ ppm +0.235 $\times$ Th ppm), a proxy for accumulated radiation damage (Figure $3 a$ ). However, there is no clear relationship between $\mathrm{ZHe}$ age and equivalent spherical radius (Figure $3 b$ ). In samples where eU values range between 2000 and 5000 ppm, 12 out of 15 ZHe ages do not follow a pronounced negative trend but rather form a "pediment-like" slope covering the age range $\sim 48 \pm 12 \mathrm{Ma}$. Cambrian sandstone samples ZG01 and 09 yielded ZHe ages between 167 and $89 \mathrm{Ma}$, with eU contents < $800 \mathrm{ppm}$. Most granite samples yielded relatively young ZHe ages (88 to $36 \mathrm{Ma}$ ) with high eU values ( 1200-4615 ppm). However, granite samples ZG06 and ZG08 yielded two low eU (<500 ppm) grains with older ZHe ages of 118 and $167 \mathrm{Ma}$, respectively. Mineralized Indosinian granite samples ZG05 and 11 from the Niuweiling and Jinjiling deposits produced grains with eU values ranging from $\sim 1200$ to 3700 ppm and $\mathrm{ZHe}$ ages between 88 and $46 \mathrm{Ma}$. Detrital zircons from the Cretaceous section in the Fengzhou Basin sample ZG02 yielded relatively low eU concentrations ( $<700 \mathrm{ppm}$ ) and relatively old ZHe ages (154-110 Ma) that are generally similar to results from nearby granite samples ZG06 and 08 with low eU values (see Table 2). The sole exception is a single grain $(81.3 \pm 5.0 \mathrm{Ma}$; eU content of $1098 \mathrm{ppm})$ that is more akin to the ZHe results from the Cambrian sandstone samples. 
Table 2. Zircon (U-Th)/He data from the Lujing uranium ore field region, South China.

\begin{tabular}{|c|c|c|c|c|c|c|c|c|c|c|c|c|c|}
\hline Grain No. & ${ }^{4} \mathrm{He}$ (ncc) & Mass ( $\mu \mathrm{g})$ & $F_{T}$ & $\mathrm{U}(\mathrm{ppm})$ & Th (ppm) & $\mathrm{Th} / \mathrm{U}$ & eU (ppm) & $\begin{array}{c}\text { Grain Length } \\
(\mu \mathrm{m})\end{array}$ & $\begin{array}{l}\text { Grain Half-Width } \\
\qquad(\mu \mathrm{m})\end{array}$ & $R s(\mu \mathrm{m})$ & $\begin{array}{l}\text { Corrected } \\
\text { Age (Ma) }\end{array}$ & $\begin{array}{l}\text { Error } \pm 1 \sigma \\
\quad(\mathrm{Ma})\end{array}$ & $\begin{array}{c}\text { Crystal } \\
\text { Morphology }\end{array}$ \\
\hline \multicolumn{14}{|c|}{ Sandstone } \\
\hline ZG01-01 & 57.28 & 7.9 & 0.81 & 432.4 & 46.0 & 0.11 & 443.2 & 220.8 & 55.1 & 66.1 & 132.2 & 8.2 & $2 \mathrm{~T}$ \\
\hline 02 & 65.97 & 11.1 & 0.81 & 357.2 & 87.2 & 0.24 & 377.7 & 291.9 & 52.6 & 66.9 & 128.2 & 7.9 & $2 \mathrm{~T}$ \\
\hline 03 & 72.86 & 7.6 & 0.80 & 571.0 & 67.4 & 0.12 & 586.8 & 220.3 & 53.4 & 64.5 & 133.3 & 8.3 & $2 \mathrm{~T}$ \\
\hline 04 & 64.54 & 9.8 & 0.81 & 430.3 & 242.4 & 0.56 & 487.2 & 265.2 & 53.0 & 66.3 & 109.7 & 6.8 & $2 \mathrm{~T}$ \\
\hline 05 & 78.73 & 6.5 & 0.79 & 766.5 & 42.2 & 0.06 & 776.4 & 212.7 & 50.0 & 60.7 & 126.5 & 7.8 & $2 \mathrm{~T}$ \\
\hline ZG09-01 & 26.53 & 8.8 & 0.81 & 254.5 & 92.3 & 0.36 & 276.2 & 221.8 & 58.8 & 69.7 & 89.4 & 5.5 & $2 \mathrm{~T}$ \\
\hline 02 & 40.53 & 9.6 & 0.80 & 250.4 & 86.3 & 0.34 & 270.7 & 271.3 & 51.2 & 64.6 & 126.7 & 7.9 & $2 \mathrm{~T}$ \\
\hline 03 & 68.32 & 10.3 & 0.82 & 479.5 & 127.6 & 0.27 & 509.5 & 260.7 & 55.4 & 68.5 & 106.2 & 6.6 & $2 \mathrm{~T}$ \\
\hline 04 & 58.59 & 6.7 & 0.77 & 489.0 & 337.8 & 0.69 & 568.4 & 244.7 & 44.9 & 56.9 & 124.7 & 7.7 & $2 \mathrm{~T}$ \\
\hline 05 & 79.57 & 6.8 & 0.80 & 544.2 & 83.0 & 0.15 & 563.7 & 217.3 & 50.6 & 61.6 & 167.0 & 10.4 & $2 \mathrm{~T}$ \\
\hline ZG02-01 & 23.20 & 2.5 & 0.71 & 649.0 & 140.3 & 0.22 & 681.9 & 161.0 & 35.0 & 43.1 & 110.6 & 6.9 & $2 \mathrm{~T}$ \\
\hline 02 & 23.08 & 2.8 & 0.71 & 482.1 & 232.6 & 0.48 & 536.8 & 172.4 & 35.5 & 44.2 & 123.8 & 7.7 & $2 \mathrm{~T}$ \\
\hline 03 & 10.18 & 2.2 & 0.70 & 203.1 & 177.1 & 0.87 & 244.7 & 145.6 & 35.4 & 42.7 & 154.0 & 9.5 & $2 \mathrm{~T}$ \\
\hline 04 & 21.81 & 2 & 0.68 & 1012.4 & 366.0 & 0.36 & 1098.4 & 135.4 & 35.9 & 42.6 & 81.3 & 5.0 & $2 \mathrm{~T}$ \\
\hline \multicolumn{14}{|c|}{ Non-Mineralized Granite } \\
\hline ZG03-01 & 84.13 & 6.4 & 0.79 & 1323.0 & 179.0 & 0.14 & 1365.0 & 206.7 & 51.1 & 61.5 & 78.3 & 4.9 & $2 \mathrm{~T}$ \\
\hline 02 & 68.46 & 5.6 & 0.76 & 1295.4 & 249.7 & 0.19 & 1354.1 & 228.5 & 42.3 & 53.5 & 74.2 & 4.6 & $2 \mathrm{~T}$ \\
\hline 03 & 261.39 & 11 & 0.80 & 4506.2 & 461.3 & 0.10 & 4614.7 & 330.7 & 47.5 & 62.3 & 42.2 & 2.6 & $2 \mathrm{~T}$ \\
\hline 02 & 39.25 & 2.8 & 0.73 & 2148.9 & 282.6 & 0.13 & 2215.3 & 153.3 & 39.8 & 47.4 & 51.5 & 3.2 & $2 \mathrm{~T}$ \\
\hline 03 & 59.61 & 3.7 & 0.76 & 3529.6 & 457.5 & 0.13 & 3637.1 & 179.3 & 40.6 & 49.7 & 36.5 & 2.3 & $2 \mathrm{~T}$ \\
\hline ZG06-01 & 75.77 & 4.3 & 0.75 & 2311.5 & 585.6 & 0.25 & 2449.2 & 203.4 & 39.8 & 49.9 & 59.1 & 3.7 & $2 \mathrm{~T}$ \\
\hline 02 & 58.07 & 3.2 & 0.69 & 3515.4 & 1703.2 & 0.48 & 3915.6 & 208.9 & 32.8 & 42.5 & 37.6 & 2.3 & $2 \mathrm{~T}$ \\
\hline 03 & 27.65 & 3.9 & 0.74 & 410.7 & 299.3 & 0.73 & 481.1 & 190.5 & 40.1 & 49.7 & 118.6 & 7.4 & $2 \mathrm{~T}$ \\
\hline ZG07-01 & 146.91 & 10.1 & 0.82 & 1753.3 & 375.1 & 0.21 & 1841.4 & 238.1 & 59.9 & 71.8 & 64.8 & 4.0 & $2 \mathrm{~T}$ \\
\hline 02 & 170.51 & 7.2 & 0.78 & 2164.3 & 277.1 & 0.13 & 2229.5 & 267.5 & 43.7 & 56.3 & 86.2 & 5.3 & $2 \mathrm{~T}$ \\
\hline 03 & 377.98 & 24.5 & 0.85 & 2913.9 & 172.4 & 0.06 & 2954.4 & 442.0 & 61.1 & 80.5 & 42.7 & 2.6 & $2 \mathrm{~T}$ \\
\hline 04 & 140.00 & 6.7 & 0.77 & 2824.4 & 578.9 & 0.20 & 2960.4 & 277.0 & 40.7 & 53.2 & 57.8 & 3.6 & $2 \mathrm{~T}$ \\
\hline ZG08-01 & 194.65 & 15.8 & 0.84 & 1633.4 & 258.3 & 0.16 & 1694.1 & 302.1 & 63.7 & 78.9 & 59.5 & 3.7 & $2 \mathrm{~T}$ \\
\hline 02 & 147.93 & 10 & 0.80 & 1832.4 & 173.6 & 0.09 & 1873.2 & 308.0 & 47.3 & 61.5 & 64.9 & 4.0 & $2 \mathrm{~T}$ \\
\hline 03 & 92.94 & 11.2 & 0.81 & 384.1 & 77.2 & 0.20 & 402.3 & 315.2 & 49.8 & 64.5 & 167.0 & 10.4 & $2 \mathrm{~T}$ \\
\hline
\end{tabular}


Table 2. Cont.

\begin{tabular}{|c|c|c|c|c|c|c|c|c|c|c|c|c|c|}
\hline Grain No. & ${ }^{4} \mathrm{He}$ (ncc) & Mass ( $\mu \mathrm{g})$ & $F_{T}$ & $\mathrm{U}(\mathrm{ppm})$ & Th (ppm) & $\mathrm{Th} / \mathrm{U}$ & eU (ppm) & $\begin{array}{c}\text { Grain Length } \\
(\mu \mathrm{m})\end{array}$ & $\begin{array}{c}\text { Grain Half-Width } \\
(\mu \mathrm{m})\end{array}$ & $R s(\mu \mathrm{m})$ & $\begin{array}{l}\text { Corrected } \\
\text { Age (Ma) }\end{array}$ & $\begin{array}{l}\text { Error } \pm 1 \sigma \\
\quad(\mathrm{Ma})\end{array}$ & $\begin{array}{c}\text { Crystal } \\
\text { Morphology }\end{array}$ \\
\hline \multicolumn{14}{|c|}{ Mineralized Granite } \\
\hline ZG05-01 & 170.43 & 14.8 & 0.81 & 1155.9 & 194.8 & 0.17 & 1201.7 & 281.6 & 53.1 & 67.0 & 78.5 & 4.9 & $0 \mathrm{~T}$ \\
\hline 02 & 57.29 & 4.4 & 0.75 & 1251.7 & 633.9 & 0.51 & 1400.7 & 196.2 & 42.0 & 51.9 & 75.3 & 4.7 & $2 \mathrm{~T}$ \\
\hline 03 & 160.68 & 7.3 & 0.80 & 2893.5 & 1330.2 & 0.46 & 3206.1 & 219.0 & 52.5 & 63.5 & 56.1 & 3.5 & $2 \mathrm{~T}$ \\
\hline ZG11-01 & 180.97 & 6.4 & 0.79 & 2475.3 & 540.9 & 0.22 & 2602.4 & 201.3 & 52.5 & 62.5 & 88.7 & 5.5 & $2 \mathrm{~T}$ \\
\hline 02 & 191.83 & 6.8 & 0.80 & 2469.2 & 932.8 & 0.38 & 2688.4 & 191.2 & 58.7 & 67.4 & 85.9 & 5.3 & $2 \mathrm{~T}$ \\
\hline 03 & 210.91 & 10.4 & 0.81 & 2629.5 & 498.3 & 0.19 & 2746.6 & 286.9 & 51.2 & 65.2 & 60.6 & 3.8 & $2 \mathrm{~T}$ \\
\hline 04 & 372.25 & 17.7 & 0.84 & 3601.0 & 410.2 & 0.11 & 3697.4 & 366.6 & 58.1 & 75.2 & 46.5 & 2.9 & $2 \mathrm{~T}$ \\
\hline FCT-01 & 3.883 & 2.3 & 0.70 & 435.6 & 219.9 & 0.50 & 487.3 & 160.6 & 33.5 & 41.6 & 28.0 & 1.7 & $2 \mathrm{~T}$ \\
\hline 02 & 10.926 & 5.6 & 0.77 & 470.7 & 405.5 & 0.86 & 566.0 & 218.6 & 44.4 & 55.4 & 28.0 & 1.7 & $2 \mathrm{~T}$ \\
\hline 03 & 7.489 & 4.9 & 0.77 & 401.3 & 256.5 & 0.64 & 461.6 & 204.2 & 43.0 & 53.2 & 27.4 & 1.7 & $2 \mathrm{~T}$ \\
\hline 04 & 3.897 & 2.2 & 0.71 & 482.7 & 242.2 & 0.50 & 539.6 & 130.9 & 39.8 & 45.8 & 27.5 & 1.7 & $2 \mathrm{~T}$ \\
\hline
\end{tabular}

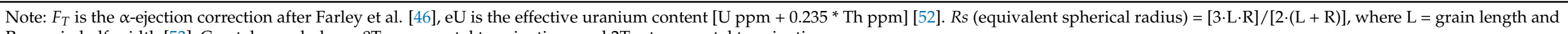
$\mathrm{R}=$ grain half-width [53]; Crystal morphology: $0 \mathrm{~T}=$ no crystal terminations and $2 \mathrm{~T}=$ two crystal terminations. 

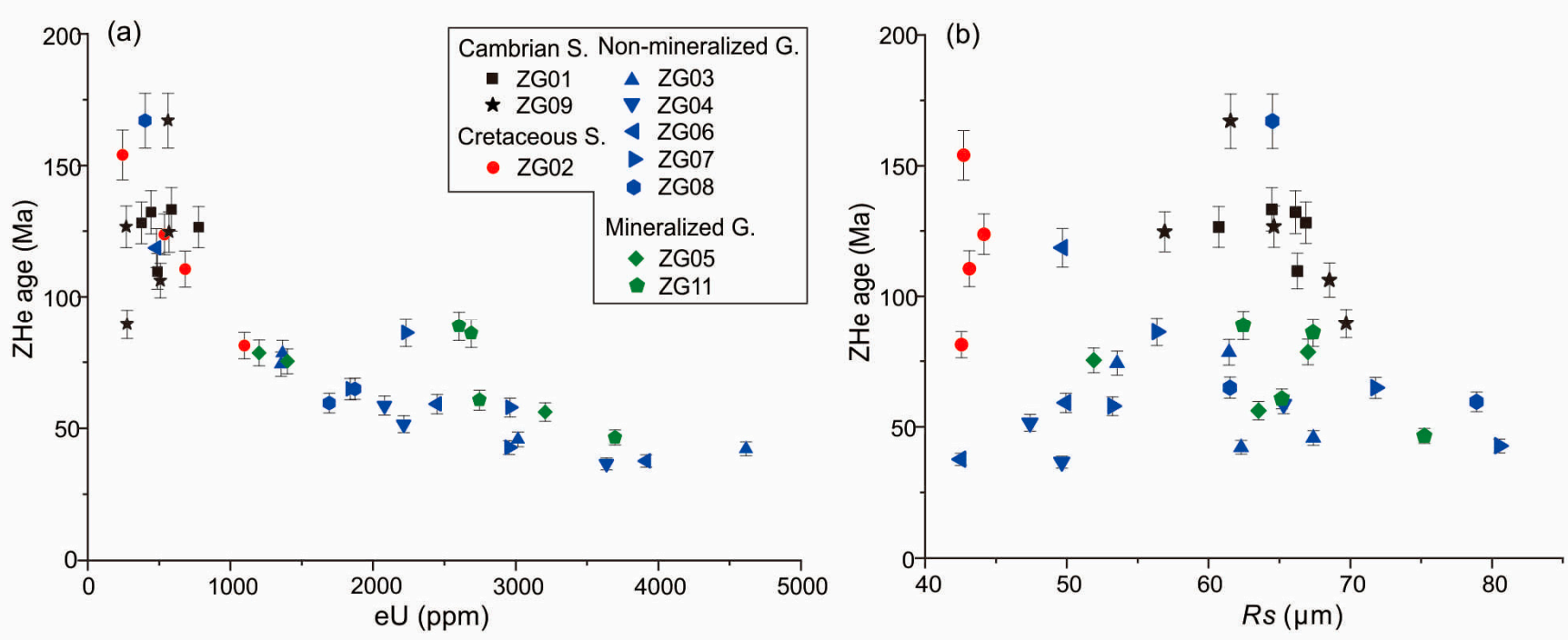

Figure 3. (a) Plots of ZHe age versus effective uranium (eU) content and (b) equivalent spherical radius (Rs) for the Lujing uranium ore field samples. S. = sandstone, G. = granite.

\subsection{Apatite Fission Track Data}

AFT data were acquired from two Cambrian sandstones and three Triassic granite samples (including mineralized sample ZG11), with at least 25 grains counted and $>80$ confined track lengths measured for each sample (Table 3, Figure 4 and supplementary material, Table S1). All central ages fall within a relatively restricted range (61.5-54.8 Ma) (Table 3). Mean track lengths (MTL) of c-axis projected confined fission tracks range from $12.84 \pm 0.15$ to $13.68 \pm 0.14 \mu \mathrm{m}$ (see Figure 2 inset) and display negatively skewed unimodal distribution patterns, with standard deviations ranging between 1.39 and $1.69 \mu \mathrm{m}$ (Table 3 and Figure 4). The mean Dpar (etch-pit widths) values of measured samples range from 1.72 to $1.93 \mu \mathrm{m}$, suggesting little compositional variation between samples (e.g., [54]). Single-grain AFT ages do not show any relationship with Dpar values or U content (Figure 4). Despite having single-grain AFT age populations that appear to spread between $\sim 80$ and $\sim 45 \mathrm{Ma}$ (Figure 4), all samples pass the chi-square test $\left(P\left(\chi^{2}\right)>5 \%\right)$, statistically consistent with their ages belonging to a single age population. AFT ages are generally younger than their corresponding ZHe ages, but older than or equal to (sample ZG08) AHe ages described below. 
Table 3. Apatite fission track data from the Lujing uranium ore field region, South China.

\begin{tabular}{|c|c|c|c|c|c|c|c|c|c|c|}
\hline Sample & No. Grains (n) & $\mathbf{N}_{\mathrm{s}}(\mathrm{n})$ & $\begin{array}{c}\rho_{\mathrm{s}} \\
\left(10^{5} \cdot \mathrm{cm}^{-2}\right)\end{array}$ & $\begin{array}{c}{ }^{238} \mathrm{U} \\
(\mathrm{ppm})\end{array}$ & $\begin{array}{c}\text { Mean Dpar } \\
\text { (Range) } \\
(\mu \mathrm{m})\end{array}$ & $P\left(\chi^{2}\right)$ & $\begin{array}{l}\text { Central Age } \\
(\mathrm{Ma} \pm 1 \sigma)\end{array}$ & $\mathrm{N}_{\text {length }}$ & $\begin{array}{l}\text { Mean Track Length } \\
(\mu \mathrm{m}) \pm \text { std Error }\end{array}$ & $\begin{array}{c}\text { Standard } \\
\text { Deviation }\end{array}$ \\
\hline \multicolumn{11}{|c|}{ Sandstone } \\
\hline ZG01 & 26 & 911 & 7.49 & 26.73 & $1.75(1.61-2.01)$ & 0.15 & $57.3 \pm 2.6$ & 84 & $13.21 \pm 0.16$ & 1.44 \\
\hline ZG09 & 36 & 908 & 5.99 & 21.30 & $1.93(1.67-2.18)$ & 0.44 & $58.1 \pm 2.4$ & 102 & $13.59 \pm 0.12$ & 1.24 \\
\hline \multicolumn{11}{|c|}{ Non-Mineralized Granite } \\
\hline ZG07 & 36 & 1385 & 11.24 & 39.70 & $1.74(1.59-1.87)$ & 0.45 & $58.1 \pm 1.9$ & 102 & $13.36 \pm 0.14$ & 1.39 \\
\hline ZG08 & 33 & 2005 & 15.01 & 54.46 & $1.72(1.41-2.09)$ & 0.13 & $54.8 \pm 1.6$ & 121 & $13.68 \pm 0.14$ & 1.56 \\
\hline \multicolumn{11}{|c|}{ Mineralized Granite } \\
\hline ZG11 & 31 & 1339 & 14.16 & 46.45 & $1.78(1.63-1.95)$ & 0.49 & $61.5 \pm 2.0$ & 110 & $12.84 \pm 0.15$ & 1.57 \\
\hline
\end{tabular}

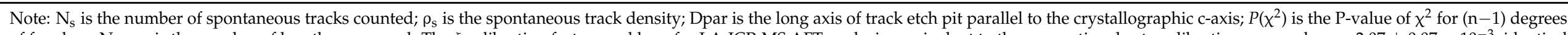

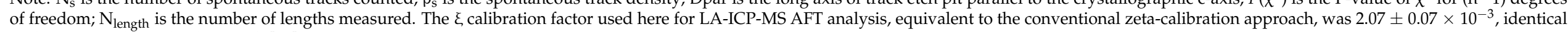
to that reported by Gleadow et al. [48]. 


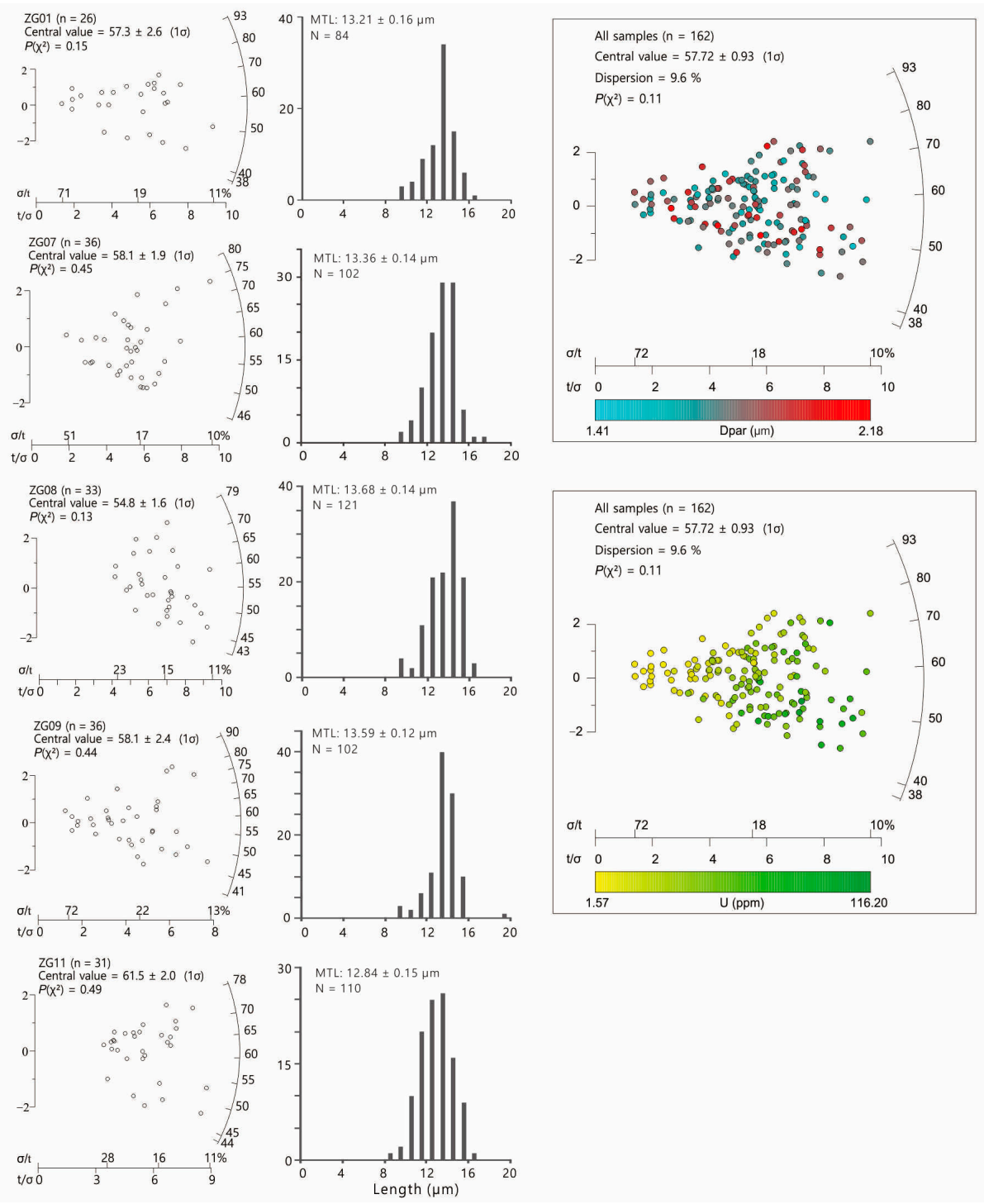

Figure 4. Radial plots of single-grain apatite fission track ages and confined fission track length distributions for Lujing uranium ore field samples. Right-hand images show radial plots for ages versus Dpar and U content. Radial plots were created with RadialPlotter [55]. MTL = mean track length, $\mathrm{n}=$ number of apatite grains, $\mathrm{N}=$ number of track lengths measured.

\subsection{Apatite $(\mathrm{U}-\mathrm{Th}-\mathrm{Sm}) / \mathrm{He}$ Data}

Thirty-one single-grain AHe data from eight samples yielded dispersed ages ranging from 168 to $18 \mathrm{Ma}$ (Table 4 and Figure 5a). The equivalent spherical radius (Rs), a proxy for grain size that allows for the direct comparison of 0-, 1-, and 2-termination crystals, and eU concentrations fall in the range of $45.8-107.5 \mu \mathrm{m}$ and $2-78 \mathrm{ppm}$, respectively (Figure $5 \mathrm{~b}$ ). Cambrian (ZG01 and 09) and Upper Cretaceous (ZG02) sandstone samples yielded AHe ages between 46 and $19 \mathrm{Ma}$, with relatively little intra-sample age dispersion. Indosinian granite samples ZG03, 07, and 08 yielded AHe ages between 66 and $34 \mathrm{Ma}$, except for one older single-grain age from sample ZG08 (166 $\pm 10.3 \mathrm{Ma})$ with markedly high ${ }^{4} \mathrm{He}$ content (Table 4). AHe ages are younger than their corresponding ZHe results, a relationship consistent with the expected nominal temperature sensitivities of the ZHe and AHe systems. In contrast, samples ZG05 and 11 collected from mineralized Indosinian granites of the Niuweiling and Jinjiling uranium deposits yield seemingly anomalous AHe ages, ranging from 168 to $82 \mathrm{Ma}$ (Table 4), which are substantially older than their corresponding ZHe ages and, in some cases, are older than the maximum age of LUOF mineralization. 
Table 4. Apatite (U-Th-Sm)/He data from the Lujing uranium ore field region, South China.

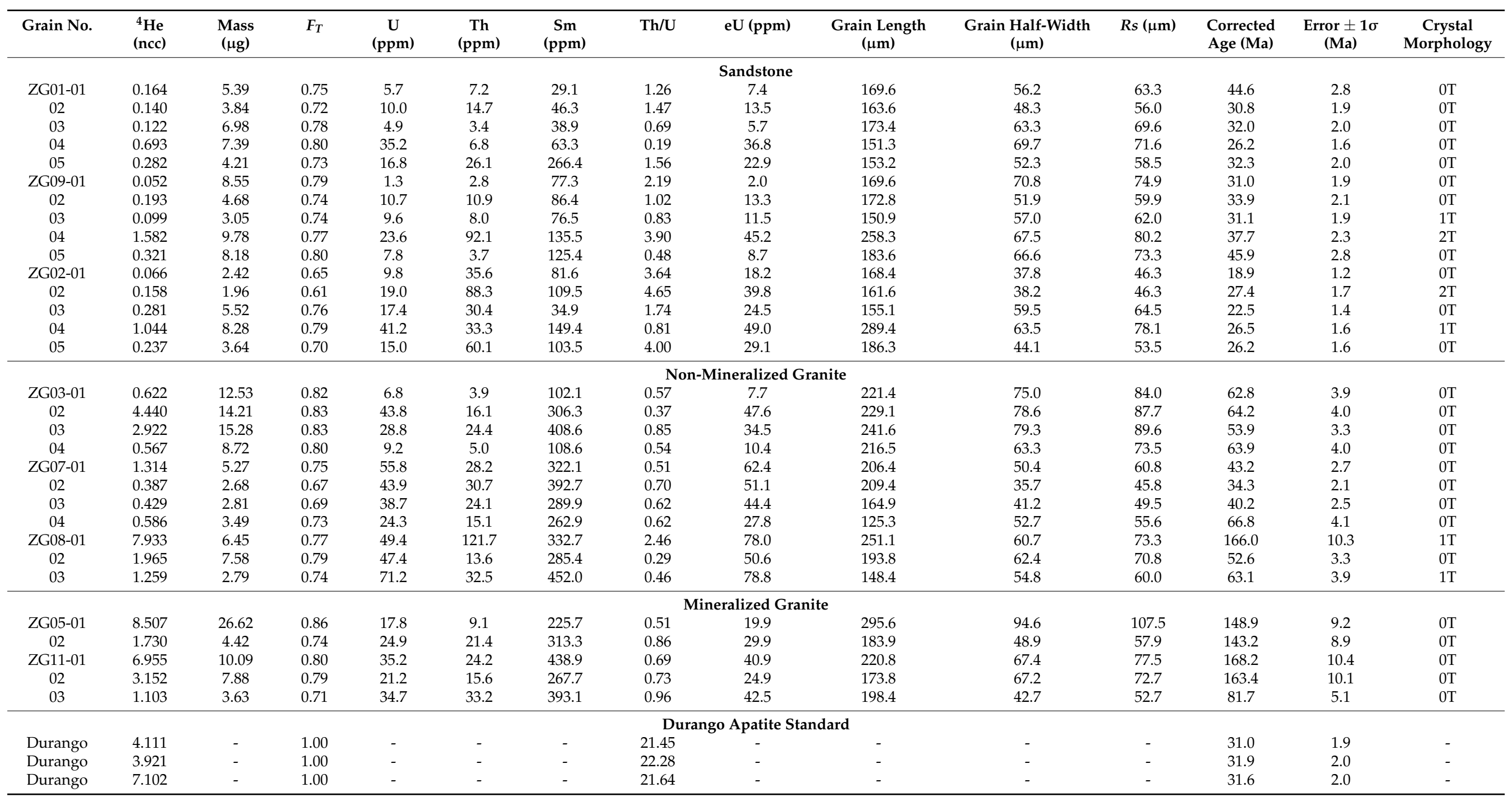

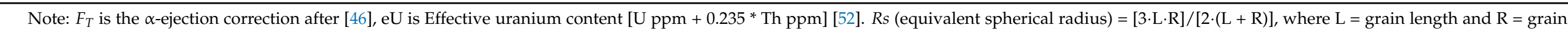
half-width [53]; Crystal morphology: $0 \mathrm{~T}=$ no crystal terminations, $1 \mathrm{~T}=$ one crystal termination and $2 \mathrm{~T}=$ two crystal terminations. 

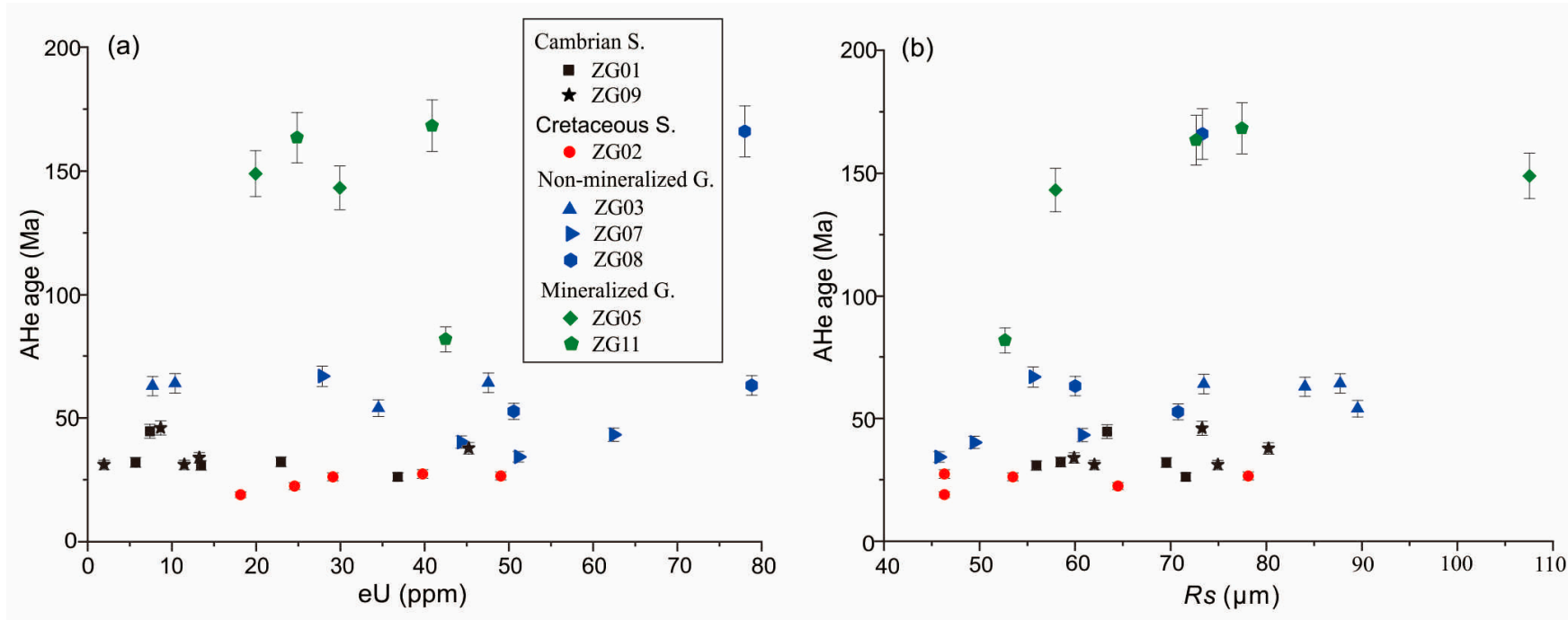

Figure 5. (a) Plots of AHe ages versus effective uranium (eU) content and (b) equivalent spherical radius (Rs) for Lujing uranium ore field samples. S. = sandstone, G. = granite.

\section{Discussion}

\subsection{Dispersion of (U-Th)/He Data}

5.1.1. ZHe Age Dispersion and Radiation Damage Effects on He Diffusion

Many of the ZHe intra-sample single-grain ages are dispersed (well beyond the $\pm 2 \sigma$ error limit of the mean age). Such dispersion may be attributed to several possible factors including the effects of radiation damage on He diffusivity, He-rich fluid inclusions, variation in crystal size, and heterogeneous intra-grain eU distribution (e.g., [52,56]). Grains from the two Cambrian sandstone samples, ZG01 and 09, define a cluster of ZHe ages (mostly within a restricted age range of $\sim 133-106 \mathrm{Ma}$ ), with no evident correlation between age and eU. The remaining 28 analyses, however, show a strong negative relationship between age and eU (Figure 3a) that is consistent with an increase in He diffusivity, even among different grains in the same sample, due to higher levels of radiation damage (e.g., [20,52,57]). This negative ZHe age-eU relationship implies that the LUOF region experienced a protracted thermal history at temperature regimes below which alpha radiation damage anneals [58].

As indicated in previous studies, there is good evidence that zircon crystals with a high degree of accumulated radiation damage often exhibit higher He diffusivity, resulting in closure temperatures $(T \mathrm{c})$ far lower $\left(<50^{\circ} \mathrm{C}\right.$ absolute temperature $)$ than that typically cited for low radiation damage grains $\left(\sim 180-200{ }^{\circ} \mathrm{C}\right)$ [20,52,57-59]. Our consistent AFT dataset can help to explain the effective temperature sensitivities of the analyzed zircons. All zircons from Cambrian and Cretaceous sandstones with eU concentrations $<1100 \mathrm{ppm}$ (Table 2) yield ZHe ages distinctly older than their corresponding AFT ages. However, two ZHe ages from samples ZG07 and 11, with elevated eU values of 2954 and 3697 ppm, yield considerably younger ages of $\sim 43$ and $46 \mathrm{Ma}$, even compared to their respective AFT results. Additionally, several zircon grains from granites ZG03, 04, and 06 with $>3600$ ppm eU yield younger ages of 45-36 Ma. This "inverted" ZHe-AFT age relationship demonstrates that the accumulation of radiation damage in the ZHe system may result in the temperature sensitivity (and the nominal Tc) being lower than that of the AFT system. The negative $\mathrm{ZHe}$ age-eU pattern could be more pronounced if samples underwent slow cooling, resulting in prolonged residence at temperatures lower than required for the annealing of alpha damage in zircon, and/or a subsequent reheating episode with partial age resetting (e.g., [58,60]). In our samples, the relatively flat relationship between most $\mathrm{ZHe}$ 
ages with eU > 2000 ppm (Figure 3a) suggests that these zircons experienced comparatively rapid cooling through a relatively low closure temperature at $\sim 48 \pm 12 \mathrm{Ma}[58,61,62]$.

\subsubsection{AHe Age Dispersion}

AHe data from the sandstone and non-mineralized granite samples exhibit intrasample reproducibility and do not show any clear relationships with either eU or Rs (Figure 5). This, together with the fact that AHe ages from ZG01, 07, 08, and 09 are younger than their corresponding AFT results, suggests that these samples cooled rapidly through the entire AHe partial retention zone $\left(\sim 80-30{ }^{\circ} \mathrm{C}\right)$ [60]. In contrast to the ZHe and AFT data, AHe ages for non-mineralized granitic samples show a generally positive linear relationship over $\sim 250 \mathrm{~m}$ of elevation (Supplementary Material, Figure S1) that is consistent with a record of denudational cooling.

By contrast, AHe data from mineralized granite samples are concordant (excluding one grain from sample ZG11; see Table 4) and considerably older than their coexisting AFT and ZHe ages and the age range reported for uranium ore formation. These "inverted" AHe ages, with respect to coexisting AFT ages and many ZHe ages, may be attributed to a number of possible factors not quantified by the applied analytical protocol, excluding differences in grain size which show no consistent relationship with AHe age [63] (Figure 5). Some of these factors have been summarized by Fitzgerald et al. [64] and Wildman et al. [65] and include possible factors such as eU zonation (e.g., [66,67]), grain fragmentation [53], He implantation from neighboring grains within the host rock [68], U-Th rich microinclusions [60], He trapping or impediment of He diffusion due to strained crystals [69], crystallographic micro-voids (e.g., [70,71]), or some combination of these factors. We are not able to attribute a specific cause/s to the present AHe age pattern. Consequently, these AHe data were not included in any thermal history modeling.

\subsection{Thermal History Modeling}

\subsubsection{Individual Sample Models}

Samples were first modeled on an individual basis, initially using solely AFT data, as AFT annealing kinetics are better understood than He diffusion processes in zircon and apatite (e.g., [72]). Next, samples were remodeled, first with the addition of AHe and then ZHe data, or only modeled with ZHe and/or AHe data if no AFT data were available. These results were then compared with one another for further assessment.

In the case of Cambrian sandstone samples ZG01 and 09, inverse thermal history models which include Late Cretaceous near-surface temperature constraints were better able to fit the observed age and track length data than their counterparts with no Late Cretaceous constraint (Figure 6). Namely, their predicted confined fission track distributions exhibit narrower peaks that are consistent with the observed apatite track length data. The best-fit $\mathrm{t}-\mathrm{T}$ paths for these models are nearly identical and are characterized by post-Cambrian heating to elevated temperatures $\left(>170{ }^{\circ} \mathrm{C}\right)$ by the Early Cretaceous, followed by Late Cretaceous rapid cooling to near-surface temperatures. This is immediately followed by a second reheating phase during the Late Cretaceous to between $\sim 80$ and $130{ }^{\circ} \mathrm{C}$ and a final phase of monotonic cooling to present-day surface temperature. 

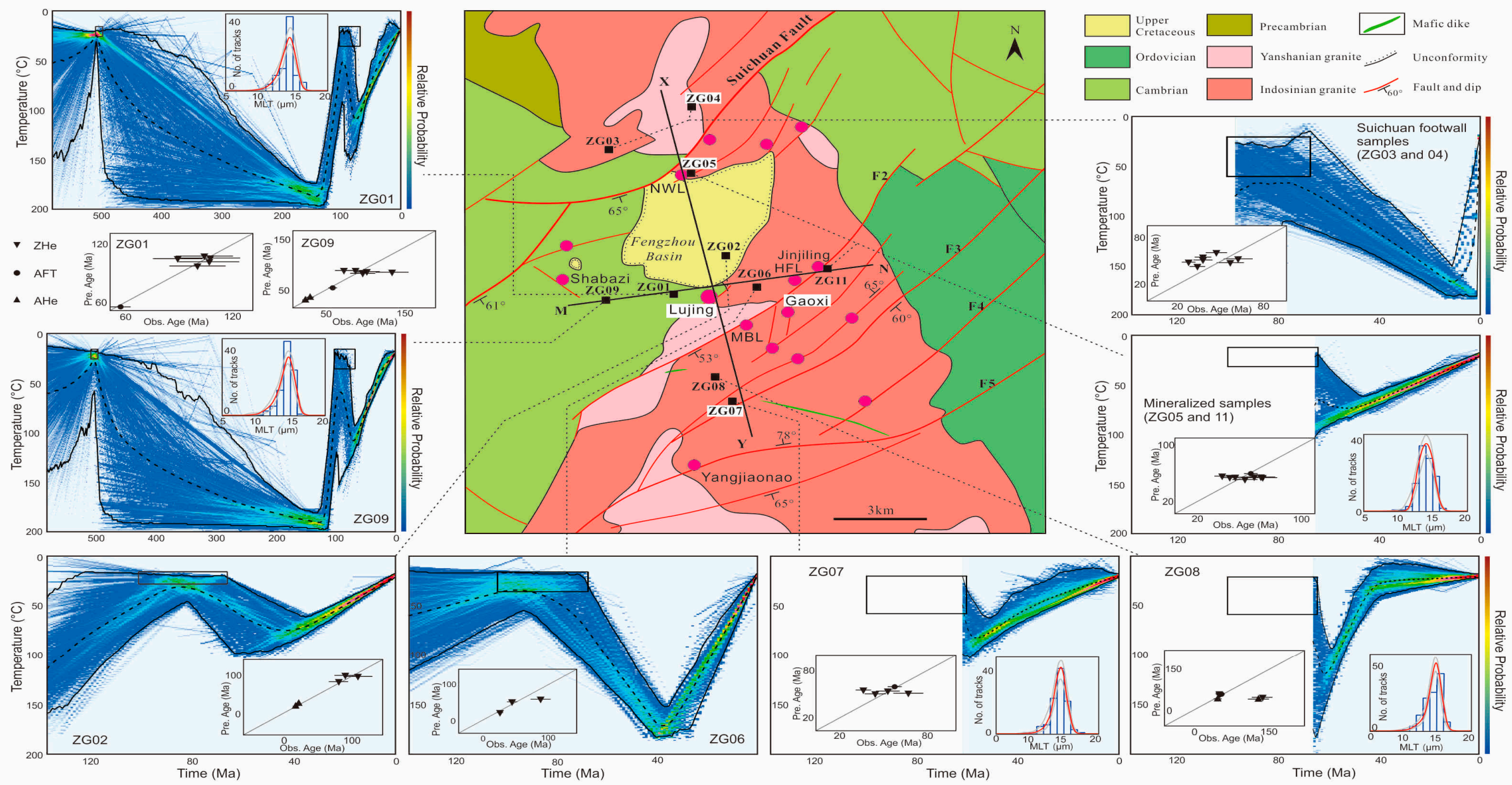

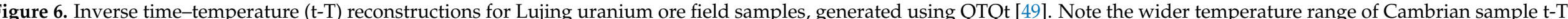

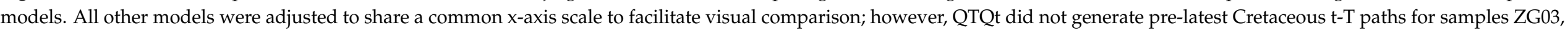

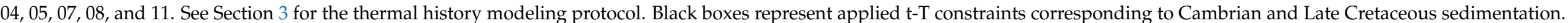

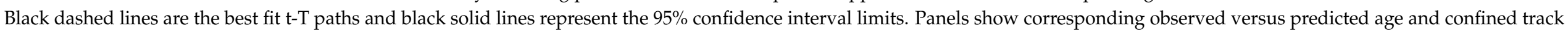

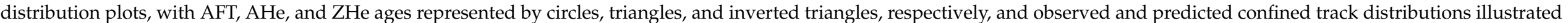
by blue bins and red curves \pm the $95 \%$ confidence interval limits (light grey curves), respectively. Pre. $=$ predicted, Obs. $=$ observed 
The inverse thermal history model of the Late Cretaceous sandstone sample ZG02 exhibits post-depositional Late Cretaceous to Paleogene heating to temperatures well within or above the AHe partial retention zone (PRZ), followed by monotonic Paleogene to Recent cooling to surface temperatures, as constrained by its modeled Oligocene AHe ages.

Inverse thermal history models of $\mathrm{ZHe}$ data from non-mineralized granite samples ZG03 and 04 (0-termination AHe ages were unable to be modeled) exhibit Late CretaceousNeogene reheating from near-surface temperatures to between $\sim 130$ and $180{ }^{\circ} \mathrm{C}$, followed by rapid cooling to surface temperature by the present-day (Figure 6). Note that the pre-Late Cretaceous reheating and cooling paths of these thermal history models, while relatively consistent with other modeling results in this study with respect to time and temperature, are not constrained by AFT and AHe data. The remaining non-mineralized samples ZG06, 07, and 08 produce similar thermal history models and exhibit a Late Cretaceous-Paleogene reheating phase, with the maximum temperature reached varying between 60 and $180{ }^{\circ} \mathrm{C}$ (Figure 6). This would require burial beneath a Late CretaceousPaleogene sequence of significant thickness and/or of low thermal conductivity to produce a blanketing effect, which would reduce the amount of burial required [73]. However, the degree of reheating may be exaggerated by the thermal history model due to the currently imperfect ZRDAAM model of Guenthner et al. [52]. Although there may be other factors at play, as outlined in Section 5.1.1, ZRDAAM often underestimates He retentivity and fails to lower the effective temperature sensitivity of high to moderate eU grains (i.e., over predicting ZHe ages) (e.g., [59,62,74]). These models then exhibit gradual cooling to near-surface temperatures by the Late Paleogene-Neogene.

Mineralized granite sample ZG11 yields a t-T model exhibiting subtle Late CretaceousPaleocene reheating into the lower AFT partial annealing zone (PAZ), followed by gradual cooling to surface temperature by the present day. As with samples ZG01, 07, 08, and 09, such a reheating event is consistent with its negatively skewed confined fission track length distributions and single-grain AFT age population that spreads from older Late Cretaceous ages to younger Paleogene ages. By contrast, the best-fit t-T path for ZG05 exhibits Late Cretaceous-Recent thermal stability at near-surface temperatures. However, a number of its acceptable $\mathrm{t}-\mathrm{T}$ paths (within the $95 \%$ confidence interval) exhibit a Late Cretaceous-Paleogene reheating pulse into the lowermost AFT PAZ, similar to the best-fit model of ZG11, suggesting that the data of ZG05 are also statistically compatible with such a thermal history. For both models, the pre-Late Cretaceous portion is not particularly well constrained by the data.

\subsubsection{Multi-Sample Model}

After modeling was carried out on an individual basis, samples were grouped together where possible and modeled jointly to both test whether the low-temperature thermal evolutions of various sample groups were controlled by their depositional, structural, or mineralization histories and to increase the robustness of the modeling results. This was deemed suitable for samples of similar formation age, such as for Cambrian sandstone samples (ZG01 and 09), or samples from the same structural block, such as those from the Suichuan Fault footwall (ZG03 and 04). Mineralized samples ZG05 and 11, which produced similar individual thermal history reconstructions, were also jointly modeled. While QTQt was unable to produce a joint inverse thermal history reconstruction for the Cambrian sandstone samples, their near identical individual model results strongly suggest that they shared a very similar thermal history (Figure 6).

The joint t-T reconstruction of samples ZG03 and 04 (ZHe data only) from the Suichuan footwall exhibits Late Cretaceous to Neogene reheating followed by rapid cooling to nearsurface temperatures from $\sim 10 \mathrm{Ma}$ to the present (Figure 6). However, the imperfect reproducibility of the observed spread in $\mathrm{ZHe}$ ages by the joint inverse $\mathrm{t}-\mathrm{T}$ model and a lack of accompanying AFT data in these samples allow for the possibility of an alternative latest Cretaceous-Recent low-temperature thermal evolution for the Suichuan footwall block. Unfortunately, AHe data from samples in the immediate Suichuan footwall (ZG03) 
and hanging wall (ZG05) were unable to be modeled due to their 0-termination morphology. Nevertheless, significant differences in AHe ages across the fault (54-64 Ma versus 143-149 Ma in the footwall and hanging wall, respectively) suggest that the Suichuan footwall may have experienced marked earliest Paleocene cooling through the AHe PRZ during Fengzhou Basin formation relative to the hanging wall. This scenario might be expected for footwall uplift and concurrent hanging wall subsidence due to normal faulting and associated Fengzhou Basin development.

The joint inverse model of mineralized samples ZG05 and 11 yields a t-T reconstruction exhibiting subtle Late Cretaceous-Paleocene reheating into the lower AFT PAZ, followed by gradual cooling to surface temperature by the present day, consistent with the individual inverse thermal history models for these samples (Figure 6).

\subsection{Geological Implications}

\subsubsection{Tectono-Thermal Evolution of the LUOF}

The low-temperature thermochronology data and inverse thermal history modeling results presented in this study suggest that outcropping Cambrian and Cretaceous sedimentary rocks and Triassic-Jurassic granites from the LUOF shared a broadly similar Late Cretaceous-Recent tectono-thermal evolution, with respect to the applied ZHe, AFT, and AHe systems (Figure 7). For many samples, the pre-Late Cretaceous thermal history is poorly constrained by the observed data. Low eU Cretaceous $\mathrm{ZHe}$ ages from samples ZG01 and 09, along with AFT ages and t-T models for these samples, are consistent with the LUOF having experienced a relatively rapid Early Cretaceous ( 130-105 Ma) cooling event, consistent with previously reported zircon fission track, ZHe, and AFT data in eastern South China [75-78]. This is interpreted as recording pronounced regional uplift and denudation that led to the development of the unconformity between Cambrian and Upper Cretaceous strata (Figure 2). This regional-scale exhumation episode is thought to have resulted from NW-SE-directed compression related to the northwestward subduction of the paleo-Pacific plate [30] and the ESE-directed retreat and subsequent WNW-oriented subduction of the Pacific slab [42,79].

Thermochronology data and $\mathrm{t}-\mathrm{T}$ models for all samples to the southeast of the SEdipping Suichuan normal fault record a subsequent latest Early Cretaceous-Late Cretaceous $(\sim 105-75 \mathrm{Ma})$ period of reheating into the lowermost PAZ to between $\sim 80$ and $150{ }^{\circ} \mathrm{C}$ (Figure 7). Due to variations in the onset of subsequent cooling to near-surface temperatures displayed in different thermal history reconstructions, the exact duration of the reheating phase cannot be readily resolved. This is attributed to some samples exhibiting significant ZHe and AHe age dispersion and not having coexisting AFT data (see Section 5.1). While inverse thermal history modeling of ZHe data from the Suichuan Fault footwall allow for a similar reheating phase, a significant jump in AHe ages across the fault from earliest Paleocene to latest Jurassic-earliest Cretaceous is consistent with the Suichuan footwall having experienced earliest Paleocene cooling through the AHe PRZ $\left(\sim 80-30^{\circ} \mathrm{C}\right)$ coeval with hanging wall reheating. An earlier onset of Suichuan footwall cooling from higher temperatures cannot be ruled out due to a lack of AFT data for those samples. Such a contrast in low-temperature thermal evolution across the Suichuan Fault is consistent will paired footwall uplift and hanging wall subsidence due to normal faulting and associated basin formation.

A concurrent reheating phase recorded throughout much of South China is interpreted to record burial during a widespread period of Late Cretaceous-Paleogene extension and related basin formation $[3,80]$. Similarly, concurrent reheating of the LUOF southeast of the Suichuan Fault is interpreted to have resulted from the formation and burial beneath a once more extensive Late Cretaceous-Paleogene Fengzhou Basin that covered much of the LUOF, as testified by the preservation of red detritus well beyond the present-day extent of the basin [43]. Slight differences in the magnitude of reheating observed in the $\mathrm{t}-\mathrm{T}$ reconstructions may be attributed to lateral variations in paleo-Fengzhou Basin thickness and thermal blanketing effects, as well as differences in modern sample elevations. 


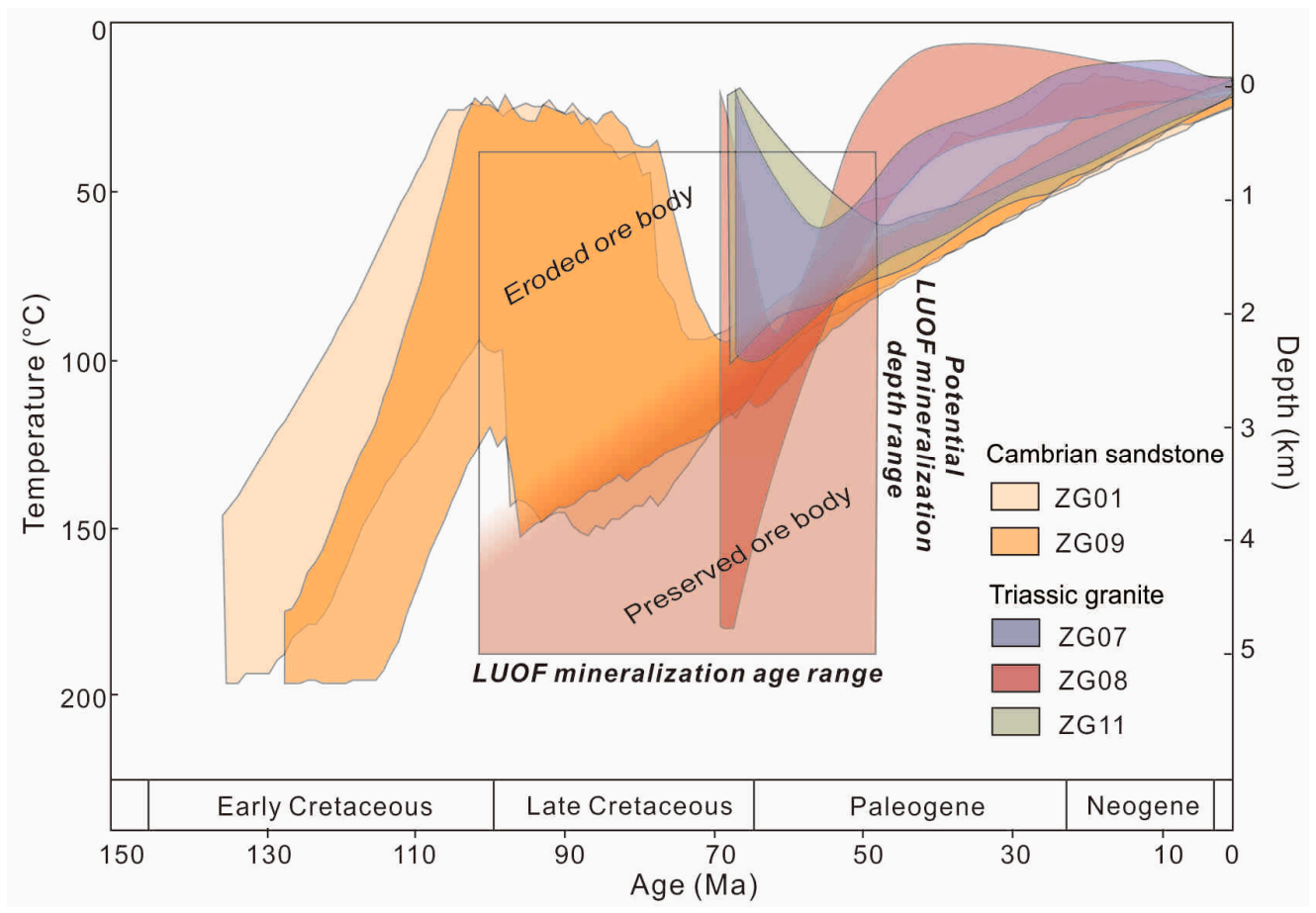

Figure 7. Cretaceous-Recent time-temperature $(\mathrm{t}-\mathrm{T})$ path envelopes consistent with low-temperature thermochronology data from the Lujing uranium ore field (LUOF) presented herein overlain by the time-temperature window of LUOF U mineralization $[3,10,11]$. LUOF uranium mineralization pressures of 152-507 bars [10] allow for possible ore formation depths between $\sim 0.6$ and $\sim 5 \mathrm{~km}$, depending on whether paleo-pressure conditions were more akin to lithostatic $(100 \mathrm{bars} / \mathrm{km})$ or hydrostatic (250 bars / km) [3]. Thermal history models were generated using QTQt [49] following the modeling protocol described in Section 3. Only inverse thermal history models of samples that also yielded AFT data are presented here, as they are better constrained. The $\mathrm{t}-\mathrm{T}$ path envelopes suggest that the LUOF experienced a phase of pronounced denudational cooling commencing in the latest Late Cretaceous to early Paleogene ( 75-50 Ma) from between $\sim 180$ and $60^{\circ} \mathrm{C}$, followed by continual cooling to surface temperatures by the present day. This is consistent with the removal of a maximum $\sim 1.2-4.8 \mathrm{~km}$ of section (assuming a paleo-geothermal gradient of $33^{\circ} \mathrm{C} / \mathrm{km}$ [81]). However, the thickness of removed overburden may be less due to any thermal blanketing effect that may have accompanied sedimentation [73]. As a result of regional denudation, a moderate to significant portion of the LUOF ore body was likely removed, with the degree of preservation dependent upon the exact timing and pressure conditions (and hence depth) of U-mineralization with respect to the onset of Late Cretaceous-early Paleogene exhumation.

Commencing at some time since the latest Late Cretaceous ( 75 Ma), the LUOF experienced a phase of moderate but pronounced exhumation and cooling (Figure 7). This cooling is observed in a broad region from central South China to the southeast coastal area $[75,78]$. It is interpreted to have occurred in response to a Late Paleogene to recent compressional regime in South China that resulted from a combination of paleo-Pacific plate subduction, India-Asia collision, and associated uplift and eastward extrusion of the Tibetan Plateau [28,75,76,81].

\subsubsection{Implications for Fengzhou Basin Formation}

The Upper Cretaceous Fengzhou Basin section comprises conglomerates containing pebble-sized clasts of granite and metamorphosed sandstone (Figure 8) and formed during a phase of regional intra-continental extension recorded throughout South China $[1,4]$. Three of four single-grain ZHe ages from the Fengzhou Basin (ZG02) predate Late Cretaceous sedimentation, as well as all granitoid ZHe ages in the LUOF, suggesting that Fengzhou detritus may have been sourced from nearby Cambrian sandstones that pro- 
duced similar Jurassic-Early Cretaceous ZHe ages. The fourth and youngest single-grain ZHe age (81 Ma) may have instead been sourced from the Indosinian granite, which yielded similar Late Cretaceous ZHe ages (Table 2). However, we also note that this grain has a considerably higher eU content ( 1100 ppm). Nevertheless, the detrital ZHe age spectra, composition, angular habit of clasts, and poor sorting of the gravels support the notion that the Fengzhou Basin conglomerates were deposited via the rapid accumulation of locally sourced sedimentary and intrusive rocks, as previously suggested for similarly aged basins throughout South China [80].
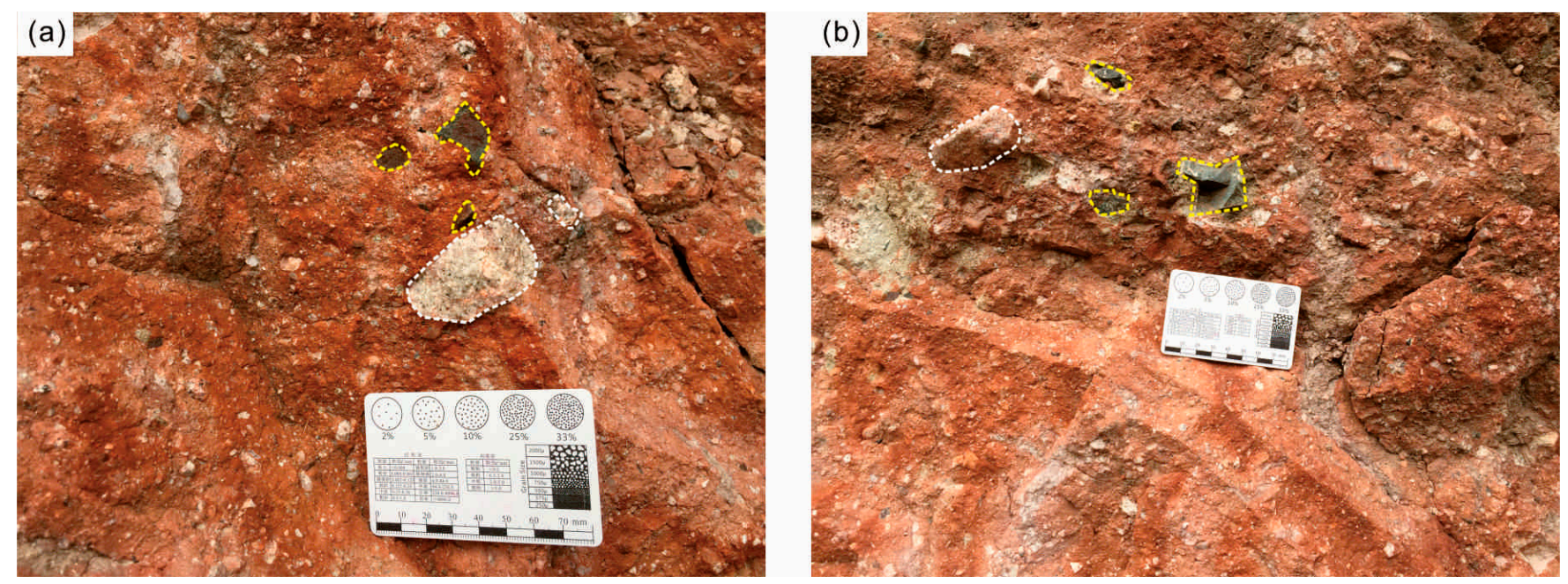

Figure 8. Field photographs of Upper Cretaceous Fengzhou Basin conglomerates from two locations, (a,b), in the Lujing uranium ore field. Several large clasts of metamorphosed sandstone and granite are highlighted by the yellow and white dashed lines, respectively. Scale bar on card in both photographs is $8 \mathrm{~cm}$ in length.

Thermal history models best-fit t-T paths for samples southeast of the Suichuan Fault which yielded AFT data (ZG01, 07, 08, 09, and 11) and are thus better constrained exhibit between $\sim 30$ and $105{ }^{\circ} \mathrm{C}$ of total Late Cretaceous reheating (Figure 6). Assuming that the observed reheating was caused solely by burial and using a paleo-geothermal gradient of $33^{\circ} \mathrm{C} / \mathrm{km}$ [82] and a paleo-surface temperature of $20 \pm 5^{\circ} \mathrm{C}$, then a paleo-stratigraphic thickness of $\sim 0.9-3.2 \mathrm{~km}$ is estimated for the Fengzhou Basin. This is similar to previous paleo-thickness estimates for the Upper Cretaceous $(1.3-2.0 \mathrm{~km})$ and Paleogene $(0.8-2.0 \mathrm{~km})$ series in South China [80]. However, the amount of burial required to have caused the observed reheating would be lowered by any thermal blanketing effect that may have accompanied the deposition of potentially low thermal conductivity sediments [73].

\subsubsection{Implications for Uranium Exploration}

The low-temperature thermochronology data presented in this study do not provide constraints for the timing of uranium mineralization in the LUOF, which previous studies suggested to have occurred at temperatures in the range of 150 to $270{ }^{\circ} \mathrm{C}$ during phases between 105 and $47 \mathrm{Ma}$ [11]. While ZHe ages from mineralized granites of the Niuweiling and Jinjiling uranium deposits (ZG05 and 11) overlap with in-situ U-Pb ages ( 75-60 Ma) from granite-related hydrothermal uranium deposits $\sim 30 \mathrm{~km}$ south of the LUOF $[7,83]$, thermal history models indicate that neither mineralized sample returned to elevated temperatures $\left(>150{ }^{\circ} \mathrm{C}\right)$ during the Late Cretaceous-Recent. Therefore, either uranium mineralization in these samples occurred prior to $\sim 90 \mathrm{Ma}$ or subsequent heating caused by the influx of hydrothermal fluids was either too short-lived and/or too distal for the grains analyzed to be recorded by the low-temperature thermochronology systems studied. 
According to conditions previously reported, uranium ore formation in the LUOF region possibly occurred at depths up to $\sim 5 \mathrm{~km}$. Assuming a paleo-geothermal gradient of $33^{\circ} \mathrm{C} / \mathrm{km}$, thermal history reconstructions suggest that post-latest Late Cretaceous ( $\sim 75 \mathrm{Ma}$ ) denudation ranged between a maximum of $\sim 1.2$ and $4.8 \mathrm{~km}$, corresponding to the upper and lower Late Cretaceous paleo-temperatures of the path envelopes, 60 and $180{ }^{\circ} \mathrm{C}$, respectively (Figure 7). These, however, are maximum estimates as paleo-geothermal gradients may have once been higher in the Fengzhou Basin due to the possible presence of lower thermal conductivity sediments, which have since been removed [73]. Nevertheless, the thermochronology data presented herein suggest that uranium ore bodies in the LUOF may have been moderately to significantly eroded due to regional Late Cretaceous-Recent exhumation, with the degree of LUOF ore body removal dependent upon the exact timing of uranium mineralization with respect to the onset of Late Cretaceous denudation. However, currently, the timing of LUOF uranium mineralization remains loosely constrained between 105 and $47 \mathrm{Ma}$ [11].

\section{Conclusions}

Newly acquired ZHe, AFT, and AHe analyses of sandstone and granite samples provide low-temperature thermochronological constraints for the Cretaceous-Recent tectonothermal evolution of the LUOF, South China. Thermal history modeling of these data indicates that the LUOF area experienced pronounced Early Cretaceous cooling, thought to have resulted from NW-SE-directed compression and associated denudation related to the northwestward subduction of the paleo-Pacific plate. This was followed by a period of latest Early Cretaceous-Late Cretaceous reheating recorded throughout the study area due to burial beneath a more extensive Fengzhou Basin that once blanketed much of the LUOF. Detrital ZHe age spectra and the presence of meta-sandstone and granite angular pebble clasts are consistent with surrounding metasedimentary and granitic rocks having supplied sediment to the Late Cretaceous section of the Fengzhou Basin. A final period of latest Late Cretaceous-Recent denudation recorded in the LUOF is regarded as a response to regional compression related to concurrent subduction of the paleo-Pacific plate, India-Asia collision, and associated uplift and eastward extrusion of the Tibetan Plateau. Maximum denudation estimates range from $\sim 1.2$ to $4.8 \mathrm{~km}$, suggesting that any LUOF uranium ore bodies which may have formed prior to the Late Cretaceous may have been moderately to significantly eroded.

Supplementary Materials: The following material is available online at https://www.mdpi.com/20 75-163X/11/2/116/s1, Table S1: Detailed AFT data of individual sample. Figure S1: Plot of ZHe, AHe and AFT ages versus sample elevation.

Author Contributions: Conceptualization, Y.S. and B.P.K.; Methodology, Y.S.; Software, S.C.B.; Investigation, Y.S., D.W. and K.W.; Writing—original draft preparation, Y.S.; writing—review and editing, B.P.K. and S.C.B.; All authors have read and agreed to the published version of the manuscript.

Funding: This research was funded by the National Natural Science Foundation of China (No. 41702076, 41702213, 42072095) and the China Scholarship Council (No. 201808360266).

Institutional Review Board Statement: Not applicable.

Informed Consent Statement: Not applicable.

Data Availability Statement: The data presented in this study are available in the supplementary material.

Acknowledgments: We thank Abaz Alimanović for assistance with (U-Th)/He analyses, and also appreciate Xiaoyan Li and Ling Chung for their help during field work and AFT data analysis. The University of Melbourne thermochronology laboratory receives support under the AuScope program of the National Collaborative Research Infrastructure Strategy (NCRIS). We acknowledge the constructive comments of three anonymous reviewers and the editors, which have greatly improved this work.

Conflicts of Interest: The authors declare no conflict of interest. 


\section{References}

1. Hu, R.-Z.; Zhou, M.-F. Multiple Mesozoic mineralization events in South China-An introduction to the thematic issue. Min. Depos. 2012, 47, 579-588. [CrossRef]

2. Mao, J.; Pirajno, F.; Cook, N. Mesozoic metallogeny in East China and corresponding geodynamic settings-An introduction to the special issue. Ore Geol. Rev. 2011, 43, 1-7. [CrossRef]

3. Hu, R.-Z.; Bi, X.-W.; Zhou, M.-F.; Peng, J.-T.; Su, W.-C.; Liu, S.; Qi, H.-W. Uranium metallogenesis in South China and its relationship to crustal extension during the Cretaceous to Tertiary. Econ. Geol. 2008, 103, 583-598. [CrossRef]

4. Li, X.-H. Cretaceous magmatism and lithospheric extension in southeast China. J. Asian Earth Sci. 2000, 18, 293-305. [CrossRef]

5. Han, J.; Wang, Y.; Wang, D.; Chen, Z.; Hou, K. Age and genesis of the granite in the Huangfengling uranium deposit, Jiangxi Province: Evideng from zircon U-Pb dating and Hf isotopes. Geol. Explor. 2011, 47, 284-293. (In Chinese with English abstract)

6. Zhang, W.; Gao, M.; Lu, C.; Huang, C.; Huang, D.; Xie, Z. Discovery of the early Indosinian granite in Lujing area, Hunan and Jiangxi border and its geological significance. Geoscience 2018, 32, 863-873, (In Chinese with English abstract).

7. Zhang, L.; Chen, Z.; Li, S.; Santosh, M.; Huang, G.; Tian, Z. Isotope geochronology, geochemistry, and mineral chemistry of the U-bearing and barren granites from the Zhuguangshan complex, South China: Implications for petrogenesis and uranium mineralization. Ore Geol. Rev. 2017, 91, 1040-1065. [CrossRef]

8. Zou, M.; Fang, S.; Xu, H.; Huang, H.; Liu, X.; Xiang, T. Liquid immiscibility for U-bearing granites of Huangfengling area, in the middle of Zhuguangshan pluton, Southern China. Chin. J. Geol. 2016, 51, 850-871, (In Chinese with English abstract).

9. Zhang, W.; He, X.; Lv, C.; Wei, J. Analysis on the metallogenic feature and ore-controlling factors in Lujing uranium orefield. Uranium Geol. 2011, 27, 81-87, (In Chinese with English abstract).

10. Shao, F.; Zhu, Y.; Guo, H.; He, X.; Shao, S. Analysis on geological characteristics of uranium metallization and prospecting potential in Lujing orefield. Uranium Geol. 2010, 26, 295-300, (In Chinese with English abstract).

11. Zhang, X.-T.; Pan, J.-Y.; Xia, F.; Zhang, Y.; Liu, G.-Q.; Liu, Y.; Zhong, F.-J. Genesis and metallogenic process of the Lujing uranium deposit, southwest Jiangxi Province, China: Constraints of micropetrography and S-C-O isotopes. Resour. Geol. 2018, 68, 303-325. [CrossRef]

12. Li, Z.; Fu, Z.; Li, J. Dynamic system analysis of metallogenesis of NNE-trending strike-slip fault-fluid-uranium mineralization in Hunan-Jiangxi border region. Geoscience 1998, 12, 522-531, (In Chinese with English abstract).

13. Li, X.; Li, J.; Fu, Z. Uranium mineralization related to strike-slip faults, Lujing orefield, border region between eastern Hunan and western Jiangxi. Earth Sci. J. China Univ. Geosci. 1999, 24, 476-479, (In Chinese with English abstract).

14. Li, J.; Chen, X.; Li, Z.; Fu, Z. Geochemical modeling for the evolution of mineralizing fluids of the Lujing uranium deposit, SE China. Geotecton. Metallog. 2000, 24, 266-273, (In Chinese with English abstract).

15. McInnes, B.I.A.; Evans, N.J.; Fu, F.Q.; Garwin, S. Application of thermochronology to hydrothermal ore deposits. Rev. Mineral. Geochem. 2005, 58, 467-498. [CrossRef]

16. Wang, Y.; Wang, F.; Wu, L.; Shi, W.; Yang, L. (U-Th)/He thermochronology of metallic ore deposits in the Liaodong Peninsula: Implications for orefield evolution in northeast China. Ore Geol. Rev. 2018, 92, 348-365. [CrossRef]

17. Márton, I.; Moritz, R.; Spikings, R. Application of low-temperature thermochronology to hydrothermal ore deposits: Formation, preservation and exhumation of epithermal gold systems from the Eastern Rhodopes, Bulgaria. Tectonophysics 2010, 483, 240-254. [CrossRef]

18. Gong, L.; Kohn, B.P.; Zhang, Z.; Xiao, B.; Wu, L.; Chen, H. Exhumation and preservation of Paleozoic porphyry Cu deposits: Insights from the Yandong deposit, southern Central Asian orogenic belt. Econ. Geol. 2020, in press.

19. Gleadow, A.J.W.; Duddy, I.R. A natural long-term track annealing experiment for apatite. Nucl. Tracks 1981, 5, 169-174. [CrossRef]

20. Reiners, P.W. Zircon (U-Th)/He thermochronometry. Rev. Mineral. Geochem. 2005, 58, 151-179. [CrossRef]

21. Reiners, P.W.; Brandon, M.T. Using thermochronology to understand orogenic erosion. Annu. Rev. Earth Planet. Sci. 2006, 34, 419-466. [CrossRef]

22. Malusà, M.G.; Fitzgerald, P.G. Fission-Track Thermochronology and Its Application to Geology; Springer Textbooks in Earth Sciences, Geography and Environment; Springer: Cham, Switzerland, 2019.

23. Zhou, A.; Dai, J.-G.; Li, Y.-L.; Li, H.-A.; Tang, J.-X.; Wang, C.-S. Differential exhumation histories between Qulong and Xiongcun porphyry copper deposits in the Gangdese copper metallogenic belt: Insights from low temperature thermochronology. Ore Geol. Rev. 2019, 107, 801-819. [CrossRef]

24. Li, X.-H.; Li, W.-X.; Li, Z.-X.; Lo, C.-H.; Wang, J.; Ye, M.-F.; Yang, Y.-H. Amalgamation between the Yangtze and Cathaysia Blocks in South China: Constraints from SHRIMP U-Pb zircon ages, geochemistry and Nd-Hf isotopes of the Shuangxiwu volcanic rocks. Precambrian Res. 2009, 174, 117-128. [CrossRef]

25. Li, L.; Lin, S.; Xing, G.; Davis, D.W.; Jiang, Y.; Davis, W.; Zhang, Y.C. 830 ma back-arc type volcanic rocks in the eastern part of the Jiangnan orogen: Implications for the Neoproterozoic tectonic evolution of South China Block. Precambrian Res. 2016, 275, 209-224. [CrossRef]

26. Zhao, G. Jiangnan orogen in South China: Developing from divergent double subduction. Gondwana Res. 2015, 27, 1173-1180. [CrossRef] 
27. Shu, L. An analysis of principal features of tectonic evolution in South China Block. Geol. Bull. China 2012, 31, 1035-1053, (In Chinese with English abstract).

28. Zhang, G.; Guo, A.; Wang, Y.; Li, S.; Dong, Y.; Liu, S.; He, D.; Cheng, S.; Lu, R.; Yao, A. Tectonics of South China continent and its implications. Sci. China Earth Sci. 2013, 56, 1804-1828. [CrossRef]

29. Yan, Q.; Shi, X.; Castillo, P.R. The late Mesozoic-Cenozoic tectonic evolution of the South China sea: A petrologic perspective. J. Asian Earth Sci. 2014, 85, 178-201. [CrossRef]

30. Li, S.; Suo, Y.; Li, X.; Zhou, J.; Santosh, M.; Wang, P.; Wang, G.; Guo, L.; Yu, S.; Lan, H.; et al. Mesozoic tectono-magmatic response in the East Asian ocean-continent connection zone to subduction of the Paleo-Pacific Plate. Earth Sci. Rev. 2019, 192, 91-137. [CrossRef]

31. Mao, J.; Cheng, Y.; Chen, M.; Franco, P. Major types and time-space distribution of Mesozoic ore deposits in South China and their geodynamic settings. Miner. Depos. 2013, 48, 267-294.

32. Gao, P.; Zhao, Z.-F.; Zheng, Y.-F. Petrogenesis of Triassic granites from the Nanling Range in South China: Implications for geochemical diversity in granites. Lithos 2014, 210, 40-56. [CrossRef]

33. Zhang, L.; Chen, Z.; Li, X.; Li, S.; Santosh, M.; Huang, G. Zircon U-Pb geochronology and geochemistry of granites in the Zhuguangshan complex, South China: Implications for uranium mineralization. Lithos 2018, 308, 19-33. [CrossRef]

34. Guo, C.; Mao, J.; Bierlein, F.; Chen, Z.; Chen, Y.; Li, C.; Zeng, Z. Shrimp U-Pb (zircon), Ar-Ar (muscovite) and Re-Os (molybdenite) isotopic dating of the Taoxikeng tungsten deposit, South China Block. Ore Geol. Rev. 2011, 43, 26-39. [CrossRef]

35. Liu, J.; Mao, J.; Ye, H.; Zhang, W. Geology, geochemistry and age of the Hukeng tungsten deposit, Southern China. Ore Geol. Rev. 2011, 43, 50-61. [CrossRef]

36. Wang, L.; Hu, M.; Yang, Z.; Qu, W.; Xia, J.; Chen, K. U-Pb and Re-Os geochronology and geodynamic setting of the dabaoshan polymetallic deposit, northern Guangdong Province, South China. Ore Geol. Rev. 2011, 43, 40-49. [CrossRef]

37. Yan, D.-P.; Zhou, M.-F.; Song, H.-L.; Wang, X.-W.; Malpas, J. Origin and tectonic significance of a Mesozoic multi-layer over-thrust system within the Yangtze Block (South China). Tectonophysics 2003, 361, 239-254. [CrossRef]

38. Deng, P.; Ren, J.; Ling, H.; Shen, W.; Sun, L.; Zhu, B.; Tan, Z. SHRIMP zircon U-Pb ages and tectonic implications for Indosinian granitoids of southern Zhuguangshan granitic composite, South China. Chin. Sci. Bull. 2012, 57, 1542-1552. [CrossRef]

39. Wu, J.; Min, M.; Zhai, J.; Luo, X.; Lai, Y.; Wei, Y. Alkali metasomatic alteration of the granite in middle Zhuguang mountain, South China. Acta Petrol. Sin. 1998, 14, 90-98, (In Chinese with English abstract).

40. Shu, L.; Deng, P.; Wang, B.; Tan, Z.; Yu, X.; Sun, Y. Lithology, kinematics and geochronology related to late Mesozoic basinmountain evolution in the Nanxiong-Zhuguang area, South China. Sci. China Ser. D Earth Sci. 2004, 47, 673-688. [CrossRef]

41. Sun, Y.; Pan, J.; Xiao, Z.; Liu, Y.; Pan, C.; Zhong, F.; Lai, J. Structural analysis and ore-prospecting prediction of the Lujing uranium orefield in middle Zhuguangshan, South China. Geol. China 2020, 47, 362-374, (In Chinese with English abstract).

42. Li, J.; Zhang, Y.; Dong, S.; Johnston, S.T. Cretaceous tectonic evolution of South China: A preliminary synthesis. Earth Sci. Rev. 2014, 134, 98-136. [CrossRef]

43. Zhang, W.-L.; Pan, K.-M. Characteristics of Fengzhou basin in Lujing uranium ore field and its significances to protecting ores. Prog. Rep. China Nucl. Sci. Technol. 2011, 2, 378-382, (In Chinese with English abstract).

44. Hu, R.-Z.; Bi, X.-W.; Su, W.-C.; Peng, J.-T.; Li, C.-Y. The relationship between uranium metallogenesis and crustal extension during the Cretaceous-Tertiary in South China. Earth Sci. Front. 2004, 11, 153-160, (In Chinese with English abstract).

45. Chen, Z.; Huang, G.; Zhu, B.; Chen, Z.; Huang, F.; Zhao, Z.; Tian, Z. The characteristics and metallogenic specialization of granite-hosted uranium deposits in the Nanling region. Geochim. Metallog. 2014, 38, 264-275, (In Chinese with English abstract).

46. Farley, K.; Wolf, R.; Silver, L. The effects of long alpha-stopping distances on (U-Th)/He ages. Geochim. Cosmochim. Acta 1996, 60, 4223-4229. [CrossRef]

47. McDowell, F.W.; McIntosh, W.C.; Farley, K.A. A precise ${ }^{40} \mathrm{Ar}^{39} \mathrm{Ar}$ reference age for the Durango apatite (U-Th)/He and fission-track dating standard. Chem. Geol. 2005, 214, 249-263. [CrossRef]

48. Gleadow, A.; Harrison, M.; Kohn, B.; Lugo-Zazueta, R.; Phillips, D. The Fish Canyon Tuff: A new look at an old low-temperature thermochronology standard. Earth Planet. Sci. Lett. 2015, 424, 95-108. [CrossRef]

49. Gallagher, K. Transdimensional inverse thermal history modeling for quantitative thermochronology. J. Geophys. Res. Solid Earth 2012, 117. [CrossRef]

50. Ketcham, R.A.; Carter, A.; Donelick, R.A.; Barbarand, J.; Hurford, A.J. Improved modeling of fission-track annealing in apatite. Am. Mineral. 2007, 92, 799-810. [CrossRef]

51. Gautheron, C.; Tassan-Got, L.; Barbarand, J.; Pagel, M. Effect of alpha-damage annealing on apatite (U-Th)/He thermochronology. Chem. Geol. 2009, 266, 157-170. [CrossRef]

52. Guenthner, W.R.; Reiners, P.W.; Ketcham, R.A.; Nasdala, L.; Giester, G. Helium diffusion in natural zircon: Radiation damage, anisotropy, and the interpretation of zircon (U-Th)/He thermochronology. Am. J. Sci. 2013, 313, 145-198. [CrossRef]

53. Beucher, R.; Brown, R.W.; Roper, S.; Stuart, F.; Persano, C. Natural age dispersion arising from the analysis of broken crystals: Part II. Practical application to apatite (U-Th)/He thermochronometry. Geochim. Cosmochim. Acta 2013, 120, 395-416. [CrossRef]

54. Carlson, W.D.; Donelick, R.A.; Ketcham, R.A. Variability of apatite fission-track annealing kinetics: I. Experimental results. Am. Mineral. 1999, 84, 1213-1223. [CrossRef] 
55. Vermeesch, P. Radialplotter: A java application for fission track, luminescence and other radial plots. Radiat. Meas. 2009, 44, 409-410. [CrossRef]

56. Danišík, M.; McInnes, B.I.; Kirkland, C.L.; McDonald, B.J.; Evans, N.J.; Becker, T. Seeing is believing: Visualization of he distribution in zircon and implications for thermal history reconstruction on single crystals. Sci. Adv. 2017, 3, e1601121. [CrossRef] [PubMed]

57. Anderson, A.J.; Hodges, K.V.; van Soest, M.C. Empirical constraints on the effects of radiation damage on helium diffusion in zircon. Geochim. Cosmochim. Acta 2017, 218, 308-322. [CrossRef]

58. Johnson, J.E.; Flowers, R.M.; Baird, G.B.; Mahan, K.H. “Inverted” zircon and apatite (U-Th)/He dates from the front range, colorado: High-damage zircon as a low-temperature $\left(<50^{\circ} \mathrm{C}\right)$ thermochronometer. Earth Planet. Sci. Lett. 2017, 466, 80-90.

59. Weisberg, W.R.; Metcalf, J.R.; Flowers, R.M. Distinguishing slow cooling versus multiphase cooling and heating in zircon and apatite (U-Th)/He datasets: The case of the McClure Mountain syenite standard. Chem. Geol. 2018, 485, 90-99. [CrossRef]

60. Flowers, R.M.; Kelley, S.A. Interpreting data dispersion and "inverted" dates in apatite (U-Th)/He and fission-track datasets: An example from the US midcontinent. Geochim. Cosmochim. Acta 2011, 75, 5169-5186. [CrossRef]

61. Orme, D.A.; Guenthner, W.R.; Laskowski, A.K.; Reiners, P.W. Long-term tectonothermal history of Laramide basement from zircon-He age-eU correlations. Earth Planet. Sci. Lett. 2016, 453, 119-130. [CrossRef]

62. Guenthner, W.R.; Reiners, P.W.; Tian, Y. Interpreting date-eU correlations in zircon (U-Th)/He datasets: A case study from the Longmen Shan, China. Earth Planet. Sci. Lett. 2014, 403, 328-339. [CrossRef]

63. Reiners, P.W.; Farley, K.A. Influence of crystal size on apatite (U-Th)/He thermochronology: An example from the Bighorn Mountains, Wyoming. Earth Planet. Sci. Lett. 2001, 188, 413-420. [CrossRef]

64. Fitzgerald, P.G.; Baldwin, S.L.; Webb, L.E.; O'Sullivan, P.B. Interpretation of (U-Th)/He single grain ages from slowly cooled crustal terranes: A case study from the Transantarctic Mountains of southern Victoria Land. Chem. Geol. 2006, 225, 91-120. [CrossRef]

65. Wildman, M.; Brown, R.; Beucher, R.; Persano, C.; Stuart, F.; Gallagher, K.; Schwanethal, J.; Carter, A. The chronology and tectonic style of landscape evolution along the elevated Atlantic continental margin of South Africa resolved by joint apatite fission track and (U-Th-Sm)/He thermochronology. Tectonics 2016, 35, 511-545. [CrossRef]

66. Meesters, A.G.C.A.; Dunai, T.J. Solving the production-diffusion equation for finite diffusion domains of various shapes: Part II. Application to cases with $\alpha$-ejection and nonhomogeneous distribution of the source. Chem. Geol. 2002, 186, 57-73. [CrossRef]

67. Farley, K.A.; Shuster, D.L.; Ketcham, R.A. U and Th zonation in apatite observed by laser ablation ICPMS, and implications for the (U-Th)/He system. Geochim. Cosmochim. Acta 2011, 75, 4515-4530. [CrossRef]

68. Spiegel, C.; Kohn, B.; Belton, D.; Berner, Z.; Gleadow, A. Apatite (U-Th-Sm)/He thermochronology of rapidly cooled samples: The effect of He implantation. Earth Planet. Sci. Lett. 2009, 285, 105-114. [CrossRef]

69. McDannell, K.T.; Issler, D.R.; O'Sullivan, P.B. Radiation-enhanced fission track annealing revisited and consequences for apatite thermochronometry. Geochim. Cosmochim. Acta 2019, 252, 213-239. [CrossRef]

70. Gerin, C.; Gautheron, C.; Oliviero, E.; Bachelet, C.; Mbongo Djimbi, D.; Seydoux-Guillaume, A.-M.; Tassan-Got, L.; Sarda, P.; Roques, J.; Garrido, F. Influence of vacancy damage on He diffusion in apatite, investigated at atomic to mineralogical scales. Geochim. Cosmochim. Acta 2017, 197, 87-103. [CrossRef]

71. Zeitler, P.K.; Enkelmann, E.; Thomas, J.B.; Watson, E.B.; Ancuta, L.D.; Idleman, B.D. Solubility and trapping of helium in apatite. Geochim. Cosmochim. Acta 2017, 209, 1-8. [CrossRef]

72. Green, P.; Duddy, I. Apatite (U-Th-Sm)/He thermochronology on the wrong side of the tracks. Chem. Geol. 2018, 488, 21-33. [CrossRef]

73. Łuszczak, K.; Persano, C.; Braun, J.; Stuart, F.M. How local crustal thermal properties influence the amount of denudation derived from low-temperature thermochronometry. Geology 2017, 45, 779-782. [CrossRef]

74. Mackintosh, V.; Kohn, B.; Gleadow, A.; Tian, Y. Phanerozoic morphotectonic evolution of the Zimbabwe Craton: Unexpected outcomes from a multiple low-temperature thermochronology study. Tectonics 2017, 36, 2044-2067. [CrossRef]

75. Wang, Y.; Wang, Y.; Li, S.; Seagren, E.; Zhang, Y.; Zhang, P.; Qian, X. Exhumation and landscape evolution in eastern South China since the Cretaceous: New insights from fission-track thermochronology. J. Asian Earth Sci. 2020, 191, 104239. [CrossRef]

76. Sun, Y.; Chen, Z.; Boone, S.C.; Zhong, F.; Tao, W. Exhumation history and preservation of the Changiiang uranium ore field, South China: Revealed by (U-Th)/He and fission track thermochronology. Ore Geol. Rev. 2021, in press.

77. Tao, N.; Li, Z.-X.; Danišík, M.; Evans, N.J.; Batt, G.E.; Li, W.-X.; Pang, C.-J.; Jourdan, F.; Xu, Y.-G.; Liu, L.-P. Thermochronological record of middle-late Jurassic magmatic reheating to Eocene rift-related rapid cooling in the SE South China Block. Gondwana Res. 2017, 46, 191-203. [CrossRef]

78. Tao, N.; Li, Z.-X.; Danišík, M.; Evans, N.J.; Li, R.-X.; Pang, C.-J.; Li, W.-X.; Jourdan, F.; Yu, Q.; Liu, L.-P.; et al. Post-250 ma thermal evolution of the central Cathaysia block (SE China) in response to flat-slab subduction at the proto-western Pacific margin. Gondwana Res. 2019, 75, 1-15. [CrossRef]

79. Chen, J.; Wang, Q.; Qiao, L.; Liu, X.; Zhang, Q. Cretaceous exhumation history of the southwestern South China Block: Constraints from fission-track thermochronology. Geol. J. 2020, 2, 1-14. [CrossRef]

80. Yin, A. Cenozoic tectonic evolution of Asia: A preliminary synthesis. Tectonophysics 2010, 488, 293-325. [CrossRef] 
81. Shu, L.S.; Zhou, X.M.; Deng, P.; Wang, B.; Jiang, S.Y.; Yu, J.H.; Zhao, X.X. Mesozoic tectonic evolution of the Southeast China Block: New insights from basin analysis. J. Asian Earth Sci. 2009, 34, 376-391. [CrossRef]

82. Yuan, Y.; Ma, Y.; Hu, S.; Guo, T.; Fu, X. Present-day geothermal characteristics in South China. Chin. J. Geophys. 2006, 49, 1118-1126, (In Chinese with English abstract). [CrossRef]

83. Zhong, F.J.; Yan, J.; Xia, F.; Pan, J.Y.; Liu, W.Q.; Lai, J.; Zhao, Q.F. In-situ U-Pb isotope geochronology of uraninite for Changjiang granite-type uranium ore field in northern Guangdong, China: Implications for uranium mineralization. Acta Petrol. Sin. 2019, 35, 2727-2744, (In Chinese with English abstract). 